\title{
The Maidenhair Tree (Ginkgo biloba, L.).
}

\author{
BY
}

A. C. SEWARD, F.R.S.,

AND

MISS J. GOWAN,

Nerwham College, Cambridge.

\section{With Plates VIII-X.}

\section{INTRODUCTORY.}

A

MONG living plants there is perhaps no more striking example of a genus which recalls the past than the Maidenhair tree of China and Japan, a type of vegetation almost unknown in a wild state, but carefully preserved in the far East as a sacred tree in the gardens of temples, and frequently cultivated in Europe and America for decorative purposes. Ginkgo is sometimes spoken of as unknown in a wild condition, but this statement has recently been challenged by Mrs. Bishop (Miss Bird) ${ }^{1}$, who speaks of having ' met with several fine specimens in the magnificent forests which surround the sources of the Gold River and the smaller Min in Western China.' The same writer, in her book entitled 'Unbeaten Tracts in Japan 2,' describes a Ginkgo tree in the Lebungé valley, which 'at a height of three feet from the ground, divides into light lofty stems, none of them less than two

1 Letter to the Standard, Aug. I 7, 1899.

2 Bird ('80), vol. ii, p. 144 .

[Annals of Botany, Vo1. XIV. No. LIII. March, 1900.] 
feet five inches in diameter.' A recent writer in the Gardeners' Chronicle ${ }^{1}$ expresses his opinion that Dr. Henry also met with the Maidenhair tree in a wild state in South-West China.

The photograph reproduced in Plate VIII is taken from a water-colour sketch executed by a native artist under the direction of $\mathrm{Mr}$. Robert Fortune during his residence in China. Our cordial thanks are due to Mrs. Robb for the generous loan of the original picture, which is of interest as representing the habit of a well-grown tree from the point of view of a Chinese artist. Several photographs of fine examples of Ginkgo trees grown in English gardens have been published from time to time in the Gardeners' Chronicle ${ }^{2}$.

The single existing species has long been recognized as a member of the Gymnosperms possessing certain features suggestive of remote antiquity, and nearly related to species which were widely distributed during the Mesozoic and Tertiary eras. While usually included in the Taxineae, Ginkgo has for many years been regarded as a peculiar generic type exhibiting numerous points of contact with the Cycadaceae, and the most cogent reason for giving full expression to its isolated position has been supplied by Hirase's discovery ${ }^{3}$ of ciliated antherozoids, a striking confirmation of Hofmeister's view ${ }^{4}$ that these motile male elements would probably be found to be developed in the pollen-tubes of Gymnosperms.

A new subdivision of the Gymnospermae, the Ginkgoaceae, has now been adopted by Engler ${ }^{5}$ and others for the reception of the monotypic genus Ginkgo, distinguished from the true Coniferae by the possession of motile male cells as well as by other characters of more or less importance. While sharing with the Cycads several characteristics, Ginkgo possesses some features which suggest comparison with the Ferns. The anatomical investigation of Palaeozoic and Meso-

1 Gardeners' Chronicle ('99), p. 467.

2 Vide the above paper for references.

3 Hirase ('97), ('98).

5 Engler and Prantl ('97), p. I9. 
zoic plants has conclusively demonstrated that Cycads and Ferns become more and more intimately associated as we descend the geologic series: we are led to the conclusion that these two classes of plants are the descendants of some common stock of remote antiquity. Our object in this contribution is to give a general account of the external features and internal structure of Ginkgo biloba, to summarize the scattered references which bear directly on the systematic position of the genus, and to present such evidence as is available towards a more accurate knowledge of the past history of the Ginkgoaceae.

The material used in our investigations was obtained chiefly from the gardens of Montpellier and Cambridge; the specimens of male flowers borne on the large Ginkgo tree in the Royal Gardens, Kew, were kindly given to us by Dr. Scott. Our thanks are due to M. Jules Daveau for female flowers produced in the Montpellier Gardens, and to Mr. Lynch for rendering us much valuable assistance in procuring material.

\section{HISTORICAL SKETCH.}

The Maidenhair tree is first mentioned under the name Ginkgo in 1712 by Kaempfer ${ }^{1}$, who gives a drawing of a shoot and an ovule and speaks of the plant as 'Ginkgo or Ginan, vulgo Itsjo ${ }^{2}$-arbor nuci fera folio adiantino.' Kaempfer's term Ginkgo was adopted by Linnaeus ${ }^{3}$ in his 'Mantissa Plantarum' of I77I. Thunberg 4 places Ginkgo biloba, L., among 'plantae obscurae,' and a few years later Smith ${ }^{5}$ refers it to the Coniferae, substituting the designation Salisburia adiantifolia for the 'uncouth generic name Ginkgo and the incorrect specific term biloba.'

In 18 I 2 Gouan ${ }^{6}$ contributed a paper on Ginkgo, in which he figured a shoot and a male flower; he retained the older

1 Kaempfer (1712), p. 8 I I ; vide also Kaempfer (1727), vol. i, p. I I6.

2 Vide Matsumura ('84), p. 86. Ginkgo biloba = Icho and Ginan-no-ki.

3 Linnaeus (1771), p. 3 I 3 .

5 Smith (1797).

+ Thunberg (1784), p. $35^{8}$.

6 Gouan ('12). 


\section{2 Seward and Gowan.-The Maidenhair}

generic name on the ground that Smith's reasons for the substitution of Salisburia were inadequate. Gouan describes a tree, received from Sir Joseph Banks, which had been growing for twenty-four years in his garden at Montpellier, where it bore male flowers in 1812 ; the author, in speaking of previous accounts of the Maidenhair tree, writes, ' plusieurs auteurs ont parlé de cet arbre, la plupart n'ont répété que ce qui avait été déjà dit.' In 1819 Jacquin ${ }^{1}$ published an account of Ginkgo, illustrated by a coloured drawing of the leaves and male flowers; he mentions the production of seeds on a tree grown in Vienna. Watson ${ }^{2}$ in 1825 also figured and described the leaves and male flowers, noting that a male plant flowered at Kew on May 8, 1824. In the following year Richard ${ }^{3}$ published good drawings of both male and female flowers and placed Ginkgo among the Taxineae. In a pamphlet by Bunge ${ }^{4}$, who had been sent by the Russian Court to Pekin, Ginkgo is included in the Amentaceae and spoken of as 'rarior in hortis et prope templa buddhaica ... pulcherrima et procerissima arbor ... talem arborem vetustissimam cujus historia usque ad tempora Dynastiae Juan refertur.' A drawing of a deeply incised leaf is given by Lindley and Hutton ${ }^{5}$ in their 'Fossil Flora' for comparison with Sphenophyllum, a Palaeozoic genus belonging to an extinct subdivision of the Pteridophytes. Endlicher ${ }^{6}$ follows Richard in the inclusion of Ginkgo among the Taxineae, and refers to the tree as indigenous in China and cultivated in Japan; he describes the leaves of the seedling as deeply cut, and notes the frequent occurrence of two or more embryos in one seed.

A paper by Zuccarini $^{7}$ in 1840 marks an advance on previous accounts in the comparison instituted between Ginkgo and the South African Cycad Encephalartos horridus as regards the form of the young leaves. In addition to

\footnotetext{
1 Jacquin ('19), p. 5 .

$s$ Richard ('26), p. I33.

5 Lindley and Hutton ('33), vol. i, Pl. XXVII.

${ }^{6}$ Endlicher ('36), p. 26I ; also ('47), p. 286.

- Zuccarini ('40). 
figures of mature leaves and short shoots, this author gives drawings of partially expanded leaves, and draws attention to the resemblance between the short shoots of the Maidenhair tree and the stems of Cycads. Two years later a brief account of Ginkgo was given by Spach ${ }^{1}$, who speaks of the flowers being produced before the unfolding of the leaves. Robert Fortune ${ }^{2}$, in his 'Wanderings in the Northern Provinces of China,' writes: 'The only tree which I met with of very large size in this district (Shanghai) is the Salisburia adiantifolia, commonly called the Maidenhair tree, from the resemblance its leaves bear to a Fern of that name. This is one of the plants which the Chinese are fond of dwarfing, and it is consequently often seen in that state in their gardens.' In a later work Fortune ${ }^{3}$ speaks of Salisburia as common in the neighbourhood of temples, and describes one temple where 'two noble trees guard the entrance, and one of them is the largest specimen of the kind I have met with; its circumference about $6 \mathrm{ft}$. from the ground is $28 \mathrm{ft}$., and it probably reaches a height of I00 ft.' In an important contribution by Eichler ${ }^{4}$ on the Morphology of Gymnosperm flowers to Martius' 'Flora Brasiliensis,' Ginkgo is placed in a separate tribe Salisburyeae. Henckel and Hochstetter ${ }^{5}$ in their 'Synopsis der Nadelhölzer' speak of Ginkgo as reaching a height of $80-100 \mathrm{ft}$.; these authors institute two garden varieties, var. variegata, characterized by the occurrence of yellowish stripes or spots on the leaves, and var. macrophylla, with large lobed leaves. Nelson ${ }^{6}$, writing in I 866 under the nom de plume 'Senilis,' refers to the Maidenhair tree as Pterophyllus Salisburiensis or Salisbury's allied Pine, and mentions the garden varieties aurea, argentea, laciniata, macrophylla, and microphylla. Carrière ${ }^{7}$ considers the origin of Ginkgo obscure, and remarks that the tree is met

1 Spach ('42), p. 298 ; vide also Göppert ('50), Pl. XLIX.

${ }^{2}$ Fortune ('47), p. I29.

4 Eichler in Martius ('52), vol. iv, pp. 409 and 445 ; vide also Saporta ('84), p. $25^{2}$.

${ }_{5}$ Henckel and Hochstetter ('65), p. 373.

${ }^{6}$ Nelson ('66), p. I63.

7 Carrière ('67), p. 7I 2. 


\section{4 Seward and Gowan.-The Maidenhair}

with only in a cultivated state, having been introduced into Europe in I754; he alludes to the variety variegata, and calls the large-leaved form var. laciniata. Siebold's 'Flora Japonica' "includes a description of Ginkgo, accompanied by a plate; the author speaks of the tree as native in Northern China, but not in Japan-'ubi praeterlapsis saeculis adnexam tradunt.'

In the more recent botanical literature we find frequent references to Ginkgo, dealing more especially with its anatomical structure and with the morphology of the female flower.

\section{DESCRIPTIVE.}

Ginkgo biloba, Linnaeus.

[Mantissa Plantarum, p. 3I3, I77I.]

1797. Salisburia adiantifolia, Smith, Trans. Linn. Soc. vol. iii, p. $33^{\circ}$.

1866. Pterophyllus Salisburiensis, Nelson, Pinaceae, p. 163.

Diagnosis.

A tree of pyramidal form reaching a height of over thirty metres, with a smooth grey bark; comparatively hardy ${ }^{2}$, and not readily killed by cold or by a smoky atmosphere; characterized among existing Gymnosperms by its flat broad leaves, deciduous in the autumn, consisting of a long and slender petiole slightly grooved on the upper surface and a lamina with venation of the Cyclopteridis type, varying considerably in size and shape, occasionally fan-shaped and entire, but more frequently divided into two halves by a more or less deep median division, or subdivided into several wedge-shaped lobes. The foliage leaves occur either scattered on long shoots or crowded at the apex of short shoots; the latter form of leaf-bearing axis often passes by apical growth into the

1 Siebold ('70), p. 72, Pl. CXXXVI.

${ }^{2}$ Nicholson ('92), p. 34 ; vide also Gardeners' Chronicle, Dec. 23, I899, p. 467 . 
long shoots bearing scattered leaves with a phyllotaxis of two-fifths.

Flowers dioecious. The male flowers, which occur in the axil of scale-leaves, have the form of a stalked central axis bearing scattered loosely disposed stamens ; each stamen consists of a slender filament terminating in a very small apical scale, and usually two, sometimes three or four, elliptical pollensacs which open by longitudinal dehiscence. The pollengrains develop a rudimentary prothallus consisting of a few cells, and before fertilization two large spirally coiled multiciliate spermatozoids are produced from the generative nuclei in the pollen-tube. The female flowers usually have the form of a long peduncle bearing two terminal elliptical ovules enclosed at the base by a collar-like envelope representing a reduced carpellary leaf. Abnormal female flowers, possessing more than two ovules, are not infrequently met with. Each ovule consists of a nucellus enclosed by a single integument, which in the ripe seed forms a thick fleshy covering surrounding a hard woody shell; the nucellus possesses a wellmarked pollen-chamber, and in the mature ovule the greater part of the nucellar tissue is reduced to a thin papery layer enclosing a large embryo-sac which usually contains two archegonia. After fertilization, which may occur either before or after the ovule has fallen from the tree, the egg-cell develops directly into an embryo with two cotyledons.

The secondary wood of Ginkgo is composed of tracheids with numerous bordered pits on the radial and not uncommonly on the tangential walls. Resin ducts occur in abundance, both in the pith and in the cortical tissues.

\section{LEAVES.}

\section{A. Cotyledons.}

The embryo shown in Pl. IX, Fig. 44, removed from the endosperm of a germinating seed, illustrates the unequal length of the two cotyledons. The smaller seed-leaf is divided into two lobes by a slit extending through about half its length, 


\section{6 Seward and Gowan.-The Maidenhair}

and the larger leaf is also slightly bilobed. The cotyledons appear to be united at the apex, but each retains a distinct epidermal layer, so that they are not strictly connate. In the upper part of the cotyledons there are two small vascular bundles, one in each lobe, containing three to four xylemelements; below the point of splitting each cotyledon is traversed by a single arc-shaped bundle consisting of about nine tracheids. In the peripheral part of the cotyledons secretory canals are seen in process of development. The stalk of a cotyledon is crescent-shaped in transverse section, and is traversed by a single vascular bundle of similar form. The epidermis is well defined, the outer walls being slightly thickened; numerous secretory canals occur in the ground-tissue, and are especially abundant on the convex side of the petiole. As Worsdell ${ }^{1}$ has shown, the vascular bundle is mesarch in structure; the xylem-elements are disposed in fairly regular radial rows, separated by comparatively broad medullary-ray cells; the protophloem forms a peripheral band of crushed tissue and a few secretory cells occur immediately beyond it. Several elements of centripetal xylem are met with on the inner side of the protoxylem. Transfusion-tracheids are few in number, but occasionally a single clump may be noticed on one side of the bundle.

Ginkgo has been described as peculiar among Conifers in possessing hypogeal cotyledons ${ }^{2}$.

\section{B. Scale-leaves.}

Plate IX, Figs. $3^{\mathrm{I}-36}$. The outermost scale-leaves from the terminal bud of a long shoot consist in the upper portion entirely of suberized tissue; in the next scale-leaves three or four peripheral layers are composed of cork cells, and in some of the bud-scales the elements of the cork-phellogen become themselves suberized ${ }^{3}$. Two vascular bundles are present in each bud-scale, containing several centripetal xylem-elements; a few transfusion-tracheids occur on each side of the

\footnotetext{
1 Worsdell ('97), p. $3 \circ 5$.

2 Tubeuf ('91), p. 96.

Cf. Haberlandt ('96), p. I23.
} 


\section{Tree (Ginkgo biloba, L.).}

bundle, and on the centripetal side of the protoxylem an arc of secretory cells extends round the protophloem, and three or four secretory sacs traverse the ground-tissue. The scaleleaves represented in Figs. $3^{1-36}$, taken from the bud of a seedling $20 \mathrm{~cm}$. in height, illustrate a gradual transition from a small triangular scale, of which the tissues are almost completely suberized, to longer scale-leaves, in which the cork tissue is confined to the apex, passing gradually into still longer and narrower leaves, in which a small emarginate lamina is differentiated from a broad and flat stalk. The expanded lower portions of the scale-leaves bear numerous hairs, which form a distinct woolly fringe to the petiole and are abundant on the small lamina. The enlarged drawings in Figs. 39 and 40 show more clearly the conspicuous hairs on the broad petiole and small laminar portion of a scale-leaf. Somewhat similar hairs, but less strongly developed, occur on the cotyledons of Pinus Pinea, L.

\section{Foliage-leaves.}

The manner of development of the foliage-leaves has been dealt with by Fankhauser ${ }^{1}$ in a paper published in 1882 . He describes the first appearance of a leaf as a transverse protuberance embracing about two-fifths of the circumference of the stem-apex ; this swelling soon exhibits a distinct emargination which becomes a fairly deep median incision. The lamina is bent over the apex, and its margin is strongly inrolled; for a time the growth is marginal, but this is succeeded by intercalary meristematic activity. As Fankhauser pointed out, the abundance of long trichomes affords an interesting peculiarity of young Ginkgo leaves ${ }^{2}$ : on some of the small scale-leaves hairs are particularly abundant, and a few occur also on the lamina of the young foliage-leaves, but they are more numerous on the leaf-stalk, which is at first almost covered with them, especially on the inner face ; in older leaves the hairs are confined to the base of the petiole, and are visible

1 Fankhauser ('82), p. 5 .

2 Ibid. ('82), p. 7, Figs. I6-18, 22 and 23. 


\section{8 Seward and Gowan.-The Maidenhair}

to the naked eye as a white downy patch. The downy hairs of the young leaves suggest a comparison with the woolly scale-leaves and young fronds of some Cycads. The older hairs may reach a considerable length, and become multicellular, consisting in the basal portion of two rows of cells containing numerous chloroplasts; these long and frequently branched filaments are attached to a slight elevation of the leaf-tissues. In the younger leaves the twisted and tangled hairs are unicellular like those of recent $C y c a d s$, and without chloroplasts. Fig. 37, Pl. IX, represents a young leaf showing a deep median incision in the lamina, and the partially inrolled margin at $a, \alpha$; the short lines on the drawing of the lamina indicate the presence of hairs. In Fig. 39, Pl. IX, a very young foliage-leaf is shown, bearing numerous hairs, and having a deeply lobed and strongly folded lamina; Fig. 4I represents an older leaf in which the hairs form a distinct patch, $h$, at the base of the petiole. The long multicellular branched hairs in Fig. 56, Pl. X, are from the edge of the petiole of a scale-leaf possessing a small lamina.

A drawing of a small seedling Ginkgo has been published by Masters ${ }^{1}$ in his paper on the comparative morphology of the Coniferae, which illustrates the deeply incised and lobed form of the lamina characteristic of the leaves of a seedling and of the vigorous long shoots of a mature plant.

The following notes are based on the examination of a seedling measuring $8.5 \mathrm{~cm}$. in length above the cotyledons :-The buds were visible in the axils of the cotyledons; the first green leaves are sub-opposite, and $2 \mathrm{~cm}$. above the seed ; the lamina of the lowest is obcuneate, and traversed by a few forked veins and short secretory canals; in the second leaf there is no definite distinction between blade and stalk. The third foliage-leaf occurs $3.2 \mathrm{~cm}$. higher on the stem; it is deeply bilobed, and each lobe is cut into three smaller segments. The fourth leaf is also deeply bilobed, and the two lobes are coarsely toothed; the petiole and lamina are more sharply differentiated than in the third leaf. 
The leaves of Ginkgo are of considerable importance as evidence of the occurrence of the genus in former periods of the earth's history; their characteristic shape and venation render them more trustworthy than most leaves as aids in the identification of fossils. Reference is made by the earliest writers on Ginkgo to the Fern-like form of the leaves, which are aptly compared with the leaves of some species of $A d i$ antum. Among existing Gymnosperms there are no species of which the leaves bear more than a distant resemblance to those of the Maidenhair tree. Among Angiosperms, an Australian plant, Hakea Baxteri ${ }^{1}$, R. Br., possesses a leaf similar in form to that of Ginkgo, but easily distinguished by the venation. It is to the fronds of Ferns that the leaves of Ginkgo approximate most closely; the reniform fronds of such species as Adiantum reniforme, L. ${ }^{2}$, A Parishii, Hook. ${ }^{3}$, Trichomanes reniforme, Forst., Lindsaya reniformis, Dry. ${ }^{4}$, Pterozonium (Gymnogramme) reniforme, Mart. ${ }^{4}$, present a fairly close agreement with the leaves of the Maidenhair tree, but the characteristic leaf of the latter, with its more or less deep median incision ${ }^{5}$, and less distinctly cordate base, may usually be readily distinguished from the fronds of Ferns. In P1. IX, Fig. 30, half of a frond of Scolopendrium nigripes, Hook. ${ }^{6}$, is represented; this illustrates a type of leaf very different from that of the British species and very similar to Ginkgo, from which it differs in the anastomosing veins. A leaf of similar form has been figured by Clarke as Scolopendrium Delavayi, Franck ${ }^{7}$.

The leaf of Ginkgo, as shown in Figs. 62-66 and 70, is characterized by the long and slender petiole and the broadly obcuneate lamina; the upper margin is usually somewhat uneven and irregular in outline, the base may be either

${ }^{1}$ Hooker, W. J. ('42), Pl. CDXXXIX and CDXL.

2 Ibid. ('46), Pl. LXXI A. $\quad{ }^{3}$ Beddome ('65), Pl. XVI.

4 Engler and Prantl, Nat. Pflanz., Polypodiaceae, p. 256, 1899.

${ }^{5}$ Cohn ('96), p. I30, quotes some lines written by Goethe on the bilobed leaf of Ginkgo.

${ }^{6}$ Hooker, W. J. ('57), Pl. IX; vide also Watson ('98).

7 Clarke ('90), p. 93, Pl. XLI. 
almost horizontal or more or less steeply inclined towards the petiole; the venation is of the Cyclopteridis type, the lowest vein in the right and left half of the lamina follows a course parallel to the edge, and gives off branches which fork repeatedly as they spread in a palmate manner towards the upper margin of the lamina ${ }^{1}$. The short secretory canals, which have their origin in the forks of the veins, are often clearly marked as short dark lines traversing the mesophyll. These canals are occasionally visible in fossil Ginkgo leaves, and by one author have been described as patches of a Fungus ${ }^{2}$. A striking feature of Ginkgo leaves is the variation in their size and shape, a fact insufficiently recognized by palaeobotanical writers ${ }^{3}$. The deeply cut lamina with more than two long and narrow segments (Figs. 63 and 66) is met with more particularly in the large leaves of vigorous long shoots; between this type and the small entire leaves characteristic of flowering shoots the difference is considerable. An unusually large bilobed leaf obtained from a tree growing in the temperate house of the Glasgow Botanic Garden measured $20 \mathrm{~cm}$. across, and a still larger leaf, $21 \mathrm{~cm}$. broad, is figured under the name Salisburia adiantifolia var. macrophylla laciniata in the tenth volume of the 'Flore des Serres".' The few examples of leaf variation represented in Pl. X, Figs. $63-67$ and 71 , are chosen principally in illustration of the resemblance between Ginkgo biloba and various Mesozoic species of the genus. More than one writer has called attention to the resemblance between the more deeply lobed leaves on the vigorous shoots of Ginkgo and certain Mesozoic forms ; Bailey, for example, speaks of such leaves as the 'fitful recollections of an ancient state ${ }^{5}$.'

A study of the anatomy of Ginkgo leaves reveals some features of interest from the point of view of comparison with Cycads and Conifers. The epidermis consists of cells

${ }^{1}$ Drude in Schenk ('79), vol. i, p. 654; Bertrand ('81), p. I78, Fig. I 29.

2 Massalongo ('59), Pl. I, Fig. I, p. 87.

3 Gardner ('83), p. 45.

4 Flore des Serres ('54), p. I I9.

5 Bailey ('96), p. 97 ; vide also Ettingshausen ('90), Pl. VII. 
of irregular outline, those of the upper surface being slightly larger than those of the lower; the cuticle is well marked but not very thick, and the stomata, with their guard-cells somewhat below the level of the epidermis, are confined to the lower face of the lamina. Bertrand ${ }^{1}$ states that there is no palisade tissue in the mesophyll; this is true of the smaller leaves on the flowering shoots, but the cells next the upper epidermis of the larger leaves are distinctly elongated at right angles to the surface. These palisade elements are rather irregular in form and often lobed, as are also the smaller mesophyll cells; the latter are usually elongated parallel to the leaf surface, and separated from one another by numerous intercellular spaces. Short canals occur between the veins, and a group of secretory cells is found above and below each vascular bundle, which may be in contact with the phloem, but are often separated from the xylem by one or more layers of parenchyma. The xylem is formed of about a dozen tracheids, which may occur either as one group or as several smaller strands separated by medullary rays; the latter appears to be the more usual arrangement in leaves from a fruiting branch, and the former in the ordinary foliage leaves. As Worsdell ${ }^{2}$ points out, the centripetal xylem is considerably reduced, and is represented by one or two tracheids. On either side of a bundle there are often one or two transfusion-elements having the form of reticulate tracheids of larger diameter than the ordinary xylem-tracheids. Some of the medullary-ray cells may be enlarged and serve as secretory elements; and a few parenchymatous cells containing crystals are present in the neighbourhood of each vascular bundle. There is no sclerenchymatous tissue, and no thick-walled hypoderm.

The petiole is traversed by two vascular bundles inclined towards one another, the xylem being made up of regular rows of pitted tracheids, numerous medullary rays, and a few centripetal elements; the transfusion-tracheids vary in number

1 Bertrand ('74), p. 3 .

2 Worsdell ('97), p. 306 ; vide also Zimmermann ('80), p. 5. 
and may be absent. In longitudinal section the spiral protoxylem-tracheids may be traced gradually into short and broad reticulated elements occupying a centripetal position. The centrifugal tracheids next the protoxylem are reticulately pitted, and these are succeeded by tracheids with alternate or crowded bordered pits.

\section{FLOWERS.}

\section{a. Female Flowers.}

The ordinary type of female flower has the form of a long naked peduncle bearing a single ovule on either side of the apex (Pl. IX, Fig. 6), the base of each ovule being enclosed by a small collar-like rim, the nature of which has been variously interpreted by different writers.

A young ovule of Ginkgo consists of a conical nucellus surrounded by a single integument (Fig. $47, i)$, terminating in the form of a two-lipped micropyle. A large pollen-chamber ( $p c$, Fig. 47 $)^{1}$ occupies the apex of the nucellus, and immediately below this two or more archegonia are developed at the summit of the embryo-sac, each of which consists of a large egg-cell surmounted by two neck-cells and a ventral canal-cell, which is cut off shortly before fertilization. In the young ovule shown in median longitudinal section in P1. IX, Fig. 47, the embryo-sac is represented at $e$ in an early stage of development. $\mathrm{Pax}^{2}$ calls attention to the many-celled archesporium of Ginkgo as a character resembling the Cycads. At a later stage, after the pollen-grains have entered the pollen-chamber, the opening of the latter becomes closed, the chamber being roofed over by a blunt protuberance of nucellar tissue, and at the beginning of June it increases in size and forms a large irregularly shaped cavity. During the growth of the embryo-sac the nucellus is gradually destroyed, and early in August a vertical outgrowth is formed from the top

\footnotetext{
${ }^{1}$ Bertrand ('78).

${ }^{2} \operatorname{Pax}(' 90)$, p. 274.
} 
of the embryo-sac, which appears as a column supporting at its apex the nucellar protuberance.

It is noteworthy that the cells surrounding the ovum are characterized by thick and deeply stained walls, and contain abundant contents and large nuclei; the walls of these cells are penetrated by well-defined pits, as in some Cycads ${ }^{1}$ and Conifers. The drawing shown in Fig. 48, P1. IX, illustrates the appearance presented in an apical view of the endosperm taken from a seed which had fallen from the tree; two archegonia are seen in an oval depression, one on each side of the vertical outgrowth of the embryo-sac. Before fertilization ${ }^{2}$ the nucleus of the egg-cell takes up a position just below the neck-cells, and a canal-cell is cut off early in September; the nucleus then moves towards the ovum and fertilization occurs. Fertilization is followed by a division of the oospore nucleus into two; each daughter-nucleus divides repeatedly, and eventually cell-membranes are laid down. The formation of the cell-walls is succeeded by division of the cells, growth being particularly vigorous in the lower part of the oospore, which constitutes the vegetative part of the embryo and gradually becomes differentiated, early in October, into the two cotyledons $^{3}$. It has often been stated that fertilization does not take place until the ripe ovules have fallen from the tree; this point has recently been investigated by Hirase ${ }^{4}$, who finds that some seeds at least contain a more or less developed embryo while still attached to the parent plant.

The ripe ovule of Ginkgo is enclosed by a thick fleshy integument, succeeded internally by a woody envelope; the upper part of the endosperm, $d$, after the removal of the hard shell (Fig. 45, b, Pl. IX), is covered by a thin papery membrane, $c$, which represents the crushed remains of the nucellus. There is a close resemblance between the seed shown in Fig. 45 and a seed of a Cycad; in each the crushed nucellar tissue is represented by a thin membrane between the woody portion

1 Treub. ('84); Ikeno ('98).

${ }^{3}$ Strasburger ('72), p. 3 I 2 .

${ }^{2}$ Hirase ('95), ('98).

${ }^{4}$ Hirase ('94). We are indebted to Dr. Donald MacAlister for a translation from Japanese of Hirase's paper. 


\section{I24 Seward and Gowan.-The Maidenhair}

of the integument and the endosperm ${ }^{1}$. Fig. 43 represents the endosperm of a fallen seed cut longitudinally; in the centre there is the blunt papilla already described, on one side of which the egg-cell of an archegonium has remained undeveloped, $a$, while on the other an embryo, $a^{\prime}$, has been produced.

The thick fleshy portion of the Ginkgo seed is rich in secretory canals, but does not possess vascular bundles; the histological structure of the seed-coats has been described by Bertrand ${ }^{2}$. The embryo-sac is usually two-angled, and the archegonia, as described by Strasburger ${ }^{3}$, occur on a line joining the two keels of the woody part of the integument. Penzig ${ }^{4}$ speaks of the occurrence of three-angled seeds, which he compares with seeds of Cycads ${ }^{5}$. It is of interest to notice the similarity between the structure of Ginkgo seeds and some of the Gymnospermous seeds described by Brongniart ${ }^{6}$ and others from Palaeozoic rocks.

The morphology of the female flower has been variously interpreted by botanists; the opinions expressed on this question, as Celakovský says, constitute 'ein lehrreiches Capitel wissenschaftlichen Suchens und Irrens ?'. The peduncle of the flower arises in the axil of a leaf, and usually bears a single ovule (Fig. 6) on either side of the apex. Strasburger in $1872^{8}$ described the ring or collar at the base of each ovule as the rudiment of the first pair of leaves of a secondary shoot; in $1879^{9}$ he spoke of the same structure as an arillus, and regarded the fleshy covering of the ovule as an integument, the peduncle with its two ovules constituting an inflorescence bearing two flowers. Strasburger described

${ }^{1}$ Cf. Bertrand ('78), p. 700.

${ }^{2}$ Ibid., loc. cit.

3 Strasburger ('72), p. $29 \mathrm{I}$.

${ }^{4}$ Penzig ('94), p. 515. Vide also Saporta ('84), p. 166, and Saporta and Marion ('85), p. $5^{8}$.

${ }^{5}$ Braun ('75).

6 Brongniart ('81); Hooker and Binney ('55), p. I 53.

7 Čelakovský ('90), p. 2.

9 Ibid. ('79), pp. 74 and $\mathbf{I} 20$. 
examples in which the peduncle bore four seeds, each supported on a slender stalk instead of two almost sessile ovules $^{1}$. Eichler ${ }^{2}$ criticized these views, and looked upon the fleshy part of the seed as an inner integument, and the collar at the base of the ovule as the outer integument. The same author, writing in $1889^{3}$, speaks of the collar as a rudimentary carpel and the peduncle and its two ovules as a single flower. Van Tieghem ${ }^{4}$ also considers the peduncle and ovules to be a single flower, the peduncle or flower-stalk being homologous with the petiole of a foliage-leaf and the two ovules comparable to the two lobes of a typical Ginkgo leaf; flowers bearing more than two ovules he compares with multilobed leaves. Van Tieghem describes the vascular system of the peduncle and its subtending leaf, and regards the collar of each ovule as a rudimentary arillus. According to Čelakovský the peduncle is a shoot bearing two or more carpels, each carpel being much reduced and transformed in its terminal portion into an ovule. He considers the peduncle with two ovules to be a reduced form, and looks upon the abnormal examples, in which one stalk bears more than two ovules, as valuable indications of the former existence of a type of Ginkgo flower which normally bore several ovules ${ }^{5}$. A Japanese author has recently summarized the chief views on the morphology of the female flower, and has himself contributed important evidence towards the solution of this vexed question ${ }^{6}$. He speaks of the peduncle as a shoot bearing two rudimentary carpels, and usually characterized by the suppression of the apical bud. Fujii adduces some interesting evidence in support of his views derived from a study of abnormal flowers in which ovules occur on more or less modified foliage-leaves (Fig. 6I, Pl. X); he found

${ }^{1}$ Strasburger ('79); vide also Göppert ('50), Pl. xlix, Fig. 5 ; Loudon ('75), Fig. 1758 ; Saporta and Marion ('85), p. 139.

${ }^{2}$ Eichler ('73).

* Van Tieghem ('69), ('91), p. I $_{4} 60$.

5 Čelakovský ('90), p. 43. Vide postea, p. 145.

${ }^{6}$ Fujii ('96); Potonié (98), p. 285, has recently suggested a comparison between the female flower of Ginkgo and the leaf of Botrychium. 


\section{I26 Seward and Gowan.-The Maidenhair}

examples of seeds produced on the marginal portions of the lamina (Fig. 6I), and in some specimens the blade of the leaf was almost entirely transformed into a group of ovules of smaller size than those borne on normal flowers. The collar at the base of the ovules was found to pass gradually into the lamina of the modified leaf. In one example figured by this author, the peduncle, which is unusually thick and bears several ovules, terminates in a scaly bud. He describes the peduncle as a shoot, and the slender stalk of each ovule is regarded as the petiole of a carpellary leaf. He found that a peduncle bearing several ovules is usually traversed by as many vascular bundles as there are ovules; each of the bundles in the peduncle divides into two in the ovule-stalks, so that each carpellary petiole possesses two small strands similar to those in an ordinary leaf-stalk.

Our own examination of normal and abnormal flowers leads us to adopt the view that the peduncle of the female flower of Ginkgo is a shoot bearing two or more carpels. Each ovule is enclosed at the base by an envelope or collar homologous with the lamina of a leaf; the fleshy and hard coats of the nucellus constitute a single integument. The stalk of an ovule, which is considerably reduced in the normal flower and much longer in some abnormal flowers, is homologous with a leaf-stalk, with which it agrees in the structure and number of the vascular bundles. The following examples afford evidence favourable to this view of the morphology of the female flower.

We attach considerable importance to the evidence afforded by abnormal flowers; deviations from the normal must be dealt with cautiously as aids to morphological interpretation, but granting the truth of the saying 'On verrait en elles tout ce qu'on voudrait y voir,' abnormalities are at least useful guides as to possible lines of evolution.

Pl. IX, Figs. 4, I 5-20. Fig. 4, P1. IX, represents the apex of a short shoot bearing a small foliage-leaf, shown in the drawing as a leaf-scar, $l$, subtending two slender stalks, each of which terminates in a small ovule. In a transverse section 
cut below the point at which the petiole becomes free from the pedicels of the ovules the vascular tissue assumes the form of a ring of bundles separated by wide medullary rays ; at a slightly higher level the ring becomes wider and forms an ellipse, and from this several tracheids pass off to form the trace of the subtending leaf, which consists of two separate collateral bundles, as in the petiole of an ordinary foliageleaf. The remaining bundles are now arranged in two groups of two each (Fig. 15), with two rudimentary additional bundles, $r, r$, consisting of radially disposed phloem-elements, but very little xylem; these die out at a higher level (Figs. i6 and 17 ). A section through the base of the pedicels at the level of their separation (Fig. I8) reveals the existence of a small bud, $b$, between the ovuliferous stalks, the inner faces of which are clothed with hairs. This small bud explains the presence of the two rudimentary bundles, and may be regarded as the aborted apex of the flowering shoot which bore the two pedicels and their ovules as lateral members. In each pedicel there are two collateral vascular strands inclined towards one another, as in the double leaf-trace of an ordinary petiole; the centripetal xylem-tracheids and transfusion-elements are however more abundant in the pedicel bundles. Fig. I9 represents a transverse section of one of the pedicels; it shows two vascular bundles and two large canals; in a section of the same pedicel later at a higher level the two bundles have coalesced to form a single strand (Fig. 20), which is accompanied by numerous transfusiontracheids and several centripetal xylem-elements.

Pl. IX, Figs. 21-23. In the ordinary female flower in which a flowering axis occurs in the axil of a leaf and bears two laterally placed ovules at the apex, the subtending leaf and the peduncle cohere at the base. A transverse section of the coherent petiole and peduncle shows the arrangement of bundles represented in Fig. $2 \mathrm{I}$; the lower part, $l$, passes up into the leaf-stalk and the upper part, $f$, becomes the peduncle. The leaf-stalk possesses the usual pair of bundles and the flower-stalk has four bundles in two pairs (Fig. 22); a short 
distance below the ovules ( $\mathrm{I}-2 \mathrm{~mm}$.) one pair of bundles unites (Fig. 23), and at a slightly higher level the remaining pair become fused into a single strand. Large canals traverse the ground-tissue of the peduncle, and transfusion-tracheids, which increase in number in the neighbourhood of the ovules, occur in association with the bundles of the flower-stalk.

Pl. IX, Figs. 2 and $3,11-14$. Figs. 2 and 3 illustrate an abnormal form of flower in which the peduncle bears three stalked ovules and a lateral unexpanded bud, $b$, seen in side view in Fig. 3. Near the base of the peduncle (Fig. II) there are two pairs of bundles and one larger separate vascular strand, five in all; at a higher level the bundles are disposed as three pairs, and a new smaller bundle (Fig. I2, $a$ ) is inserted between two of the pairs. Each vascular strand contains one or two centripetal tracheids, and some transfusion-elements are present. A second additional bundle is met with at a still higher level (Fig. I3), the centre of the axis being now occupied by a secretory canal, $c$. Still higher, we find that the first additional bundle has become elongated tangentially, and is accompanied by numerous transfusion-tracheids and some centripetal xylem-elements; both of the additional bundles have moved nearer the centre of the peduncle. Fig. I4 shows the arrangement of the tissue at a higher level; the additional bundles form a broken ring surrounding the central canal, $c$, and these strands supply the lateral bud. Each of the three pairs of peripheral bundles passes into an ovuliferous stalk where the double strand unites into an arcshaped bundle. The lateral bud ( $b$, Figs. 2 and 3 ) shows three small protuberances, which in section present the appearance of rudimentary ovules.

Pl. IX, Figs. I and 5. In the first example (Fig. I) the stout peduncle of a female flower bears five ovuliferous stalks, each of which is traversed by a pair of bundles. Fig. 5 represents a peduncle bearing two sessile lateral ovules at the apex, and at a lower level three small ovules on slender pedicels. 


\section{B. Male Flowers.}

The male flower ${ }^{1}$ has the form of a catkin borne in the axil of a scale-leaf on a short shoot, with one or more bracts (Fig. 8, b) attached to the peduncle ${ }^{2}$. Usually two (Fig. 9), but not infrequently three, and more rarely four pollen-sacs (Fig. 7) depend from a slender filament terminating distally in a small knob, which appears as a broader fleshy disc, bearing four pollen-sacs in the stamen shown in Fig. 7. The pollensacs dehisce by a longitudinal slit on the inner side (Fig. 9). The wall of the sac consists of four to seven cells in breadth, and thickening bands occur on the walls of the outer layers. Thibout ${ }^{3}$ has recently given an account of the structure of the pollen-sacs and filament; he suggests that the stamens with three pollen-sacs may point to the former existence of a type of Ginkgo stamen in which three was the normal number. The pollen-grains $(30 \mu \times 10 \mu)$ are characterized by a median depression along their major axis, and as Thibout points out they recall those of Cycads rather than the pollengrains of Conifers ${ }^{4}$.

The peduncle of the male flower adheres at its base to the subtending bract; in a section through the common base the vascular bundle of the peduncle is semicircular in form, and the two bundles of the bract complete the circle. In the free peduncle the xylem consists of nine or ten separate strands arranged in the form of an ellipse; there appears to be little or no centripetal xylem or transfusion tracheids. The filament of a stamen is traversed by an axial bundle composed of about twelve tracheids radiating from a protoxylem strand (Fig. $5 \circ, p x)$; two or three centripetal xylem-elements occur (cf. Fig. 50), also a few large transfusion-tracheids (to).

At maturity-about the end of April-a pollen-grain con-

${ }^{1}$ Goebel ('81), p. 705 (Pl. VI, Figs. 25 and 26), has described the development of the stamens of Ginkgo.

2 Van Tieghem ('91).

${ }^{3}$ Thibout ('96), p. 175 .

4 Thibout ('96), p. I99. Vide also Capellini and Solms ('92), PI. V; Wieland ('99), p. $3^{89}$. 


\section{30 Seward and Gowan.-The Maidenhair}

tains a prothallus of three to five cells and the exine embraces two-thirds of the circumference. The pollen-tube grows towards the top of the nucellus, and at the beginning of July the distal end of the tube becomes branched and fixes itself near the apical nucellar protuberance, the pollen-grain end being next the archegonia. The nucleus of the innermost prothallus-cell divides, and one daughter-nucleus is pushed out from the mother-cell; this cell (' body-cell' of Strasburger) grows in size and reaches its maximum about the middle of August. Some days before fertilization the cell divides, and finally two large antherozoids are produced ${ }^{1}$.

\section{SHOOT AND RoOT ${ }^{2}$.}

\section{i. Leaf-traces.}

The course of the leaf-traces in shoots of Ginkgo has been described by Thomas ${ }^{3}$, Geyler ${ }^{4}$, and other writers. Close to the apex of a shoot ${ }^{5}$ the vascular bundles of a foliage-leaf make their appearance as double strands, and the leaf-traces in the upper part of the shoot have the form of distinct bundles which in the lower region constitute a continuous ring. Each double leaf-trace passes through four internodes before becoming a part of the stele; the double form of the trace is especially characteristic of Ginkgo ${ }^{6}$. The first indication of the separation of a leaf-trace from the stele of the shoot, as seen in transverse section, is the intrusion of two blunt wedges

${ }^{1}$ Hirase ('94), p. 360, and ('98); Strasburger ('92), P1. I; Belajeff ('97), p. 338 ; Webber ('97).

${ }^{2}$ For references to the anatomy of Ginkgo, vide Mohl ('32), p. 4I I ; Hartig ('48), p. 123 ; Göppert ('50), pp. 54 et seq., Pls. IX and XIII ; Dippel ('62) and ('63); Kraus ('64), pp. 146, \&c., and ('86), pp. 102, \&c. ; Van Tieghem ('70), p. I86 ; Bertrand ('74); Höhnel (77), p. 535; Moeller ('82), Fig. 2I ; Nakamura ('83), p. 25; Gardner ('83); Göppert ('83); Schulz ('83); Saporta ('84), pp. 20 et seq. ; Essner ('86), pp. Io, \&c. ; Felix ('94).

3 Thomas ('65).

* Geyler ('67); vide also Nägeli [quoted by Bertrand ('74)].

3 Strasburger ('72), p. 327 ; vide also Fankhauser ('82).

- Williamson ('83), Pl. XXXIII, Figs. 28 and 29. 
of the pith into the xylem-ring (Fig. $24, p, p$ ); a third smaller wedge (Fig. 25, $p^{\prime}$ ) makes its appearance between the two larger ones, and this rapidly extends in a radial direction until the vascular cylinder is broken through (Fig. 26); finally, the two groups of xylem and phloem ${ }^{1}$ become free (Fig. 27), and pass outtwards (Fig. 53, lt) into the leaf-stalk accompanied by one or more large secretory canals $(S)$. Close to the base of the leaf-lamina each bundle divides into two and then breaks up into the dichotomously branched veins.

\section{ii. Young stem (seedling).}

A transverse section of a young stem $2.5 \mathrm{~mm}$. in diameter presents the following features:-The epidermis is cuticularized, but no cork has been formed in the hypodermal tissues; the xylem occurs as a ring made up of groups separated by wide medullary rays, each group being composed of radial rows of tracheids and medullary rays one to two cells in width; the phloem is approximately equal to the xylem in depth, and the crushed protophloem is succeeded by secretory cells. The protoxylem elements are often compressed and separated from the radially disposed tracheids by one or two layers of parenchyma. Long secretory sacs occur in the pith and canals traverse the cortex; the cortical region also includes scattered cells containing crystals of calcium oxalate.

\section{iii. Short and long Shoots.}

The type of stem represented by a seedling is also met with in the terminal elongating shoots of the adult tree; the phyllotaxis of these long shoots may be $\frac{2}{5}, \frac{3}{8}$, or $\frac{5}{13}$; each leaf bears in its axil a bud which in the third year often develops into a short shoot producing a few crowded leaves. The short shoot elongates from year to year and bears an apical group of leaves, the older portion being covered with the crowded leaf-scars of former years, presenting an appearance

1 Cf. Cordaites (Dadoxylon) as figured by Williamson ('77), Pl. IX, pp. 44 and $4^{6}$. 


\section{I32 Seward and Gowan.-The Maidenhair}

comparable on a small scale (Fig. 42) to the main stem of a Cycad. A short shoot may, after several years' growth, elongate into a long shoot ${ }^{1}$ bearing scattered leaves, and in some instances the short shoot may branch (Fig. 42), like the trunks of Cycas and some other genera of Cycads.

In the long shoot the xylem and phloem form a complete ring; secretory canals traverse the tissues of both pith and cortex, and secretory cells are especially abundant at the periphery of the phloem. The medullary rays of young long shoots were found to be usually one cell deep, rarely two or three cells in depth. The tracheids bear one to three rows of bordered pits on their radial walls, and when more than one row is present the pits of adjacent series may occur on the same level; single rows of pits are fairly abundant on the tangential walls of the xylem-elements.

In comparing a series of sections cut through the upper part of a short shoot and the lower portion of the long shoot into which it has elongated, one notices certain differences in the structure. The wood of the short shoot is rather looser in texture (Fig. $5^{8}$ ), more particularly at the inner margin of the xylem, where the rows of tracheids are separated by broad medullary rays as in Cycadean wood (Figs. 53 and $5^{8}$ ). In the cortex of a short shoot the phloem is succeeded by ordinary parenchyma, including crystal-sacs; in the long shoots a broken ring of thick-walled and crushed secretory cells succeeds the phloem, and farther out crystal-sacs are abundant in the parenchymatous tissue. Canals are met with in the pith and cortex of both long and short shoots. The pithcells of the short shoots are more or less spherical and irregularly disposed, while in the long shoots they are more rectangular and in regular vertical series. With the exception of certain species of Cephalotaxus, as recently pointed out by Rothert ${ }^{2}$, secretory canals are not found in the pith of true Conifers. In the short shoots the phloem is characterized by the occurrence of thick-walled fibres. Reticulately pitted tracheids are abundant at the point of exit of a leaf-trace, and

\footnotetext{
1 Bertrand ('74), p. 24.
}

${ }^{2}$ Rothert ('99). 
a few short elements of this type may occur on the centripetal side of the foliar strand.

The drawing shown in Fig. 59 represents the tracheids of a leaf-trace as seen in a tangential section through the cortex of a short shoot; the smaller group, $x$, may belong to an axillary bud. In Fig. Io a short shoot is seen in radial longitudinal section ; the contraction of the pith has produced an appearance suggestive of a discoid pith like that of the Walnut or the extinct genus Cordaites.

\section{iv. Older branches.}

There are a few points in the structure of older branches worthy of note. The secondary phloem contains numerous thick-walled fibres with transverse or oblique cross-walls ; with these are associated parenchymatous cells and large sievetubes with sieve-plates in small groups on the radial walls (Fig. 52 ). These several elements do not follow a regular or constant order of succession in a radial direction, but are variously arranged. In the secondary bast single swollen parenchymatous cells occur full of crystals; similar sacs are found also in the cortex, pith, and medullary-ray tissues. In the autumn wood bordered pits are abundant on the tangential walls of the tracheids (Fig. 49), the pit-canals are often twisted, and appear as a cross when seen in surface-view. The bordered pits on the radial walls of the tracheids are often separated from one another by transverse radial bars ${ }^{1}$. The medullary rays are two to five cells deep, and their cells have simple oblique pits, but in some cases these appear to be bordered; the branched medullary-ray cells of an old branch shown in Fig. 57 are un-. usual in form, and pursue a somewhat obliquely radial course ${ }^{2}$ across the face of the tracheids.

Strasburger ${ }^{3}$ has described the anatomy of a Ginkgo stem fifty-eight years old ; it is unnecessary therefore to recapitulate the facts he records. 


\title{
I34 Seward and Gowan.-The Maidenhair
}

\author{
v. Roots.
}

Van Tieghem ${ }^{1}$ and other writers have described some of the anatomical features of the roots of Ginkgo. Fig. $5 \mathrm{I}, \mathrm{Pl}$. X, represents a section of a young primary root; the piliferous layer produces long unicellular hairs, of which traces can be seen in the photograph; this is succeeded by one or two layers of rectangular suberized cells and four layers of cortical elements; next to this tissue there are two layers, or sometimes only one layer, of cells with strong thickening bands on their radial walls (Fig. $5 \mathrm{I}, e$ ). The pericycle is made up of seven to eight layers of almost spherical cells, but opposite the two xylem plates this tissue is narrower. A radial longitudinal section through the place of origin of a lateral root demonstrates the existence of several short tracheids with bordered pits between the spiral protoxylem and the tracheids of the lateral root. The spiral tracheids of the protoxylem are succeeded by elements with reticulate pitting, and beyond which there are tracheids with large transversely elongated simple pits which gradually pass into the elements with smaller bordered pits ${ }^{2}$.

In the seedling root the stele is at first diarch; but at a higher level the splitting of first one and then the other xylem strand produces a tetrarch structure; at a still higher level a fifth protoxylem group appears, and afterwards a sixth is found on the opposite side of the stele, thus producing an hexagonal arrangement (P1. X, Fig. 55). Scattered xylemelements $\left(\right.$ metaxylem $^{3}$ ) appear in the pith, and these may be abundant enough to entirely replace the central conjunctive tissue. In the hypocotyl the cambium forms rows of centrifugal xylem except at the two ends of the stele, the latter gradually increases in diameter, and from the two ends of the longer axis of the xylem-ring, groups of tracheids pass out as the cotyledon-traces; the stele then becomes closed again,

1 Van Tieghem ('70), p. 195; ('87), p. 105; also Van Tieghem and Douliot ('88), p. 349, and Strasburger ('72), p. 350.

${ }^{2}$ Cf. Dippel ('62), Pl. VI, Fig. I.

3 Van Tieghem ('87), p. I05. 


\section{Tree (Ginkgo biloba, L.).}

and assumes the form of a ring consisting of seven or eight collateral bundles of xylem and phloem.

In a fairly old root the annual rings are not so well marked as in the stem, and the walls of the tracheids are thinner; the medullary rays which contain a few crystal-sacs vary in height from one to seven cells. The xylem parenchyma includes some crystal-containing cells, and thick bast fibres are abundant in the phloem.

\section{FOSSIL GINKGOACEAE.}

To attempt a detailed description of the fossil records which have a direct or indirect bearing on the geological history of the Ginkgoaceae would necessitate an unreasonable extension of the present paper. Our aim must be confined to giving, as briefly as possible, a general summary of the more trustworthy evidence which may enable us to form an opinion as to the antiquity of the Ginkgoaceae, and as to the geographical distribution of fossil species in former periods of the earth's history. In I 88 I Oswald Heer ${ }^{1}$ published an interesting article, in which he summarized the data furnished by Palaeozoic, Mesozoic, and Tertiary fossils towards the past history of the existing type. The list of plants enumerated includes certain forms which cannot be satisfactorily shown to bear a close relationship to Ginkgo, and, on the other hand, subsequent research enables us to make additions to Heer's list of extinct species.

Palaeozoic leaves. Among the genera recorded from Carboniferous and Permian rocks, which have been regarded as more or less closely related to the existing Maidenhair tree, we have Ginkgo itself, Ginkgophyllum, Baiera, Saportaea, Trichopitys, Dicranophyllum, Rhipidopsis, Whittleseya, Psygmophyllum, Cordaites, Gomphostrobus, Trichophyllum, and others.

Ginkgo (Salisburia). Under the name Salisburia primigenia, Saporta and Marion ${ }^{2}$ have figured some fossils described by Grand'Eury from the middle Permian of the

1 Heer ('81).

${ }^{2}$ Saporta and Marion ('85), p. I45, Fig. 74. 


\section{I36 Seward and Gowan.-The Maidenhair}

Urals, which bear a fairly close resemblance to the leaves of the recent species. These fragments, while agreeing in shape with some types of Ginkgo leaves, may also be compared with a Russian fossil described by Schmalhausen ${ }^{1}$ as Rhipidopsis ginkgoides from strata classed as Jurassic, but which Zeiller ${ }^{2}$ has shown probably belong to the Permo-Carboniferous period. Renault ${ }^{3}$ has figured a leaf from the Permian of Martenet, which may be compared with a specimen named by Schmalhausen Ginkgo integerrima ${ }^{4}$; and Archangeli ${ }^{5}$ records $G$. primigenia from the Permian of Italy.

Psygmophyllum (Ginkgophyllum). Saporta ${ }^{6}$ proposed the name Ginkgophyllum for leaves of a cuneate form with an entire or dissected lamina attached to the stem by a decurrent leaf-stalk. He includes under this term leaves described by some authors ${ }^{7}$ as species of Noeggerathia, Psygmophyllum, and other genera. We have no evidence, beyond such as is afforded by their not very close resemblance to the leaves of Ginkgo, that these fossils have any claim to be regarded as representatives of the Ginkgoaceae.

Saportaea. This generic name was instituted by Fontaine and White ${ }^{8}$ for two species of leaves from the Virginian CoalMeasures, which resemble those of Ginkgo biloba. In themselves the fossils are insufficient as evidence of the existence of the Ginkgoaceae in the Coal Period forests, but they are of interest as agreeing closely in form with those of recent species.

Rhipidopsis. Schmalhausen ${ }^{9}$ provided this genus for some leaves with a palmate lamina and dichotomously branched veins, from Petschoraland, which he placed in the Salisburieae. The genus has been recorded more recently by Kurtz ${ }^{10}$ from

1 Schmalhausen ('79), Pl. VIII, Fig. 3.

3 Renault ('96), p. r38.

5 Archangeli ('95).

2 Zeiller ('96).

4 Schmalhausen ('79), P1. XVI.

7 Lindley and Hutton ('32), Pls. XXVIII and XXIX ; vide also Schimper ('70), p. I92 ; Schenk ('83), Pl. XLIII.

8 Fontaine and White (' 80 ), Pl. XXXVIII.

9 Schmalhausen ('79), p. 5० ; vide also Zeiller ('96).

10 Kurtz ('94). 
Permo-Carboniferous rocks in Argentina. As in the case of the Palaeozoic species, the leaves of this genus naturally suggest a comparison with Ginkgo, but we have no satisfactory evidence beyond external resemblance.

Gomphostrobus. This genus, described by Marion ${ }^{1}$ from the Permian of Lodève and placed by him in the Salisburieae, bears too remote a resemblance to Ginkgo to be included in the list of probable near allies of the recent species. Potonié ${ }^{2}$ speaks of the genus as possibly a member of the Psilotaceae, but this opinion has little to support it.

Dicranophyllum. A Palaeozoic genus characterized by the possession of narrow linear forked leaves attached to leaf cushions which cover the surface of the branches ${ }^{3}$. Such evidence as we possess regarding the nature of the reproductive organs does not lend support to the views of some authors that Dicranophyllum should be included in the Ginkgoaceae.

Trichopitys. Saporta ${ }^{4}$ has applied this name to Permian and Jurassic leaves characterized by a deeply dissected lamina with forked acicular segments. The type-species, Trichopitys heteromorpha from the Permian of Lodève, presents a fairly close resemblance to Dicranophyllum, but we have not sufficient evidence to warrant its inclusion in the Ginkgoaceae. A Jurassic plant, originally described by Lindley and Hutton as Solenites furcata ${ }^{5}$, is named by Saporta Trichopitys Lindleyana ${ }^{6}$; this species should probably be referred to Baiera, and may be a near ally of Ginkgo.

The genus Cordaites, although it cannot reasonably be classed with the Ginkgoaceae, is of interest as affording certain points of contact with Ginkgo $^{7}$ which suggest a prob-

${ }^{1}$ Marion ('90), p. $80^{2}$; vide also Zeiller ('92), p. ıоI, Pl. XV, Fig. I 2.

${ }^{2}$ Potonié ('93), p. I92, Pls. XXVII, XXVIII, and XXXIII.

${ }^{3}$ Founded by Grand'Eury ('77), p. I02I ; vide Lima ('88); Renault ('96), Pls. LXXXIX and LXXXI, p. 376 .

4 Saporta ('84), p. 230, Pl. CLII.

5 Lindley and Hutton ('37), Pl. CCIX.

6 Saporta ('84), p. 266, Pl. CLV.

7 Williamson ('77) and ('83) has described the double leaf-trace of Cordaites similar to that of Ginkgo; vide also Scott ('96), p. I7, who compares the stamens of Ginkgo and Cordaites. 


\section{38 Sewvard and Gowan.-The Maidenhair}

able alliance between the two genera. The genera Whittleseya and Trichophyllum have been compared with Ginkgo ${ }^{1}$, but our knowledge of these fossils is too incomplete to admit of more than speculation of little or no scientific value.

Baiera. This genus calls for a fuller notice as including several species of Palaeozoic and Mesozoic age, some of which are almost certainly near relatives of the Maidenhair tree. Baiera was first defined by Braun ${ }^{2}$, who applied the name to some Triassic leaves which agree with Ginkgo in shape, but differ in possessing a lamina with more numerous and narrower segments. Braun and Schenk ${ }^{3}$ included Baiera among the Ferns, and it is not improbable that some of the species may be best compared with such recent Ferns as Actinopteris radiata, Link. (Pl. X, Fig. 67), or with species of Schizaea, e.g. S. dichotoma, Sw. (Pl. X, Fig. 60), S. elegans, Sw., and others.

Valuable evidence as to the Gymnospermous nature of some types of the genus is afforded by examples of flowers and seeds described by Schenk ${ }^{4}$, Heer ${ }^{5}$, and other authors. Among Palaeozoic leaves referred to Baiera, we have Baiera virginiana, Font. and Wh. ${ }^{6}$, from the Permian of Virginia, B. Raymondi, Ren. ${ }^{7}$, from Charmoy, and some other species. The genus was probably most widely spread during the Jurassic period, but there is fairly strong evidence in favour of extending its range to the Palaeozoic epoch. In considering the range of Baiera it is important to bear in mind the absence of any well-marked distinguishing features between some species of this genus and some of the more dissected, forms of Ginkgo leaves. Among Jurassic leaves of the Ginkgo type [e.g. G. digitata (Brongn.) and G. Phillipsi, Nath.] it is easy to select a series illustrating a gradual transition from leaves with an entire lamina to those with a dissected lamina and linear segments, conforming in all respects to Braun's

${ }^{1}$ Lesquereux ('79), P1. IV ; Saporta and Marion ('85), p. I44, Fig. 73 C.

2 Braun ('43), p. 20.

3 Schenk ('67).

4 Ibid.

${ }^{5}$ Heer ('76), p. $5^{\text {I. }}$

${ }^{6}$ Fontaine and White (' 80 ), Pl. XXXVII.

7 Renault ('96), p. I 38 , Fig. 5 I. 
genus Baiera and to leaves which some authors include in the genus Feanpaulia.

Triassic. Among Triassic species referred to Baiera and Ginkgo, the following may be mentioned:-Baiera multifida, Font., from Virginia ${ }^{1}$, which bears a close resemblance to Salisburia palmata, Ratte, from Australia ${ }^{2}$; Ginkgo crenata ${ }^{3}$ (Brauns), from Steinstedt near Braunschweig; Baiera furcata, Heer, founded on a fragment from the Swiss Trias ${ }^{4}$; Baiera (?) Steinmanni, Solms, from the Rhaetic of Chili ${ }^{5}$, similar to $B$. Schenki, Feist. ${ }^{6}$, from South Africa, and B. Virginiana, F. and Wh.; Baiera Munsteriana (Presl), B. taeniata, Schenk, from Germany ${ }^{7}$; Ginkgo obovata, Nath., G. minuta, Nath. (possibly a Fern ; cf. Rhacopteris sp.), Baiera Geinitzi, Nath., $B$. marginata, Nath., B. paucipartita, Nath., from Scania ${ }^{8}$. From the Ipswich rocks of Queensland, Shirley ${ }^{9}$ has recently described several species of Ginkgo, e.g. G. antarctica, Sap., G. bidens, Ten-woods (very similar to Baiera gracilis, Bunb., from the Inferior Oolite of Yorkshire), G. Simmondsi, Shir., and Baiera ginkgoides, Shir.

Some of the best examples of Rhaetic species of Baiera have been described by Schenk. This author also describes and figures some fossils under the name Stachopitys Preslii ${ }^{10}$, which are no doubt male flowers, of which the stamens bear five or six pollen-sacs arranged as a verticil at the end of the filaments.

Furassic and Wealden. The genera Ginkgo and Baiera ${ }^{11}$ are abundantly represented in Jurassic floras, and especially from European localities. We cannot attempt a critical examination of all the described species, but must confine ourselves to the enumeration of most of the examples recorded from various latitudes. The drawings of Ginkgo leaves shown in Pl. X, Figs. 62-66 and Fig. 70, illustrate the range of variation in the form of the lamina in the recent species, and serve as warnings

1 Fontaine ('83), Pls. XLV-XLVII.

${ }^{3}$ Nathorst ('78).

- Feistmantel ('89).

9 Shirley ('98).

4 Heer ('76).

${ }^{7}$ Schenk ('67) and ('87).

${ }^{10}$ Schenk ('67).

11 The genus Czekanozeskia, frequently included in the same family with Ginkgo, is omitted as being in all probability but remotely connected with the recent genus.
${ }^{2}$ Ratte ('87).

${ }^{5}$ Solms-Laubach ('99).

${ }^{8}$ Nathorst ('78). 


\section{Seward and Gowan.-The Maidenhair}

against accepting all the fossil types of Heer and other authors. The species Ginkgo digitata, originally described by Brongniart as a Fern ${ }^{1}$, is a common fossil in the Inferior Oolite beds of the Yorkshire coast, and one of the best examples of a Jurassic representative of the Maidenhair tree (Fig. 46, Pl. IX). The leaves of this species are in some forms practically indistinguishable from those of Ginkgo biloba (Figs. $4^{6}$ and 54). Some of the smaller and more deeply lobed examples are usually referred to a distinct species, Ginkgo Huttoni (Sternb.), but these bear too near a likeness to some forms of the recent species (e.g. Figs. 63,64 , and $66, \mathrm{Pl} . \mathrm{X}$ ) to be specifically separated from the more typical examples of Ginkgo digitata (P1. IX, Fig. 46). The fossil leaf shown in Fig. 69, P1. X, from the Stonesfield slate, is probably not specifically distinct from the Ginkgo digitata (Brongn.), but it is of interest as affording evidence of the existence of the genus in the Stonesfield slate flora, from which it has not been previously recorded. The Wealden leaves from North Germany, originally named by Dunker Cyclopteris digitata, Brongn.', can hardly be distinguished from the Jurassic species.

Among other species of Ginkgo and Baiera may be mentioned Ginkgo Whitbiensis, Nath., Baiera gracilis, Bunb., $B$. Phillipsi, Nath., B. Lindleyana (Schimp.), all of which occur in British Oolite strata. From Northern latitudes $\mathrm{Heer}^{3}$ has described numerous leaves which he refers to Ginkgo and Baiera; from Siberia we have such species as Ginkgo pusilla, G. concinna (cf. Baiera gracilis), G. lepida (cf. Salisburia nana, Daws. ${ }^{4}$, from Canada, B. Phillipsi, Nath., and Ginkgo sibirica, Heer), $G$. sibirica, $G$. digitata, Baieva longifolia, and $B$. pulchella. The specimens from Franz Josef Land described by Nathorst ${ }^{5}$ and by Newton and Teall ${ }^{6}$ as Ginkgo polaris

1 Brongniart ('28), Pl. LXI bis.

2 Dunker ('46), Pls. I, V, and VI ; and Schenk ('71), Pl. XXIV.

3 Heer ('68-'83), passim.

4 Dawson ('85 and '93).

5 Nathorst in Nansen ('97), Vol. ii, p. 486.

6 Newton and Teall ('97), P1. XXXVIII. [Since this was written, a fuller account of Ginkgo leaves from Franz Josef Land has been published by Nathorst in Part III of the Scientific Results of the Norwegian North Polar Expedition, I $893^{-1} 896$, edited by Fridtjof Nansen.] 
may be compared with Ginkgo Whitbiensis from England and with $G$. pulchella from Siberia ; they are chiefly of interest as extending the Arctic range of the genus.

From rocks which may be of Inferior Oolite age at Cape Stewart on the east coast of Greenland, Hartz ${ }^{1}$ has recorded Ginkgo Hermelii; from Bornholm ${ }^{2}$ we have G. digitata and Baiera pulchella. From China and Japan leaves of both Ginkgo and Baiera are recorded by Schenk ${ }^{3}$ and Yokoyama ${ }^{4}$ respectively.

Feistmantel has determined an imperfect Indian specimen on very slender evidence as Ginkgo sp. ${ }^{5}$ The plant-beds of India have not furnished any specimens which afford satisfactory evidence of either Baiera or Ginkgo in the PermoCarboniferous or Mesozoic floras of that region.

Cretaceous and Tertiary. Cretaceous rocks of North America, Greenland, and other regions have afforded several examples of Ginkgo leaves, such as Ginkgo polymorpha, $G$. Laramiensis ${ }^{6}$ [very similar to $G$. adiantoides of Tertiary age ; Fig. 29, P1. IX], G. pusilla, Daws., from Vancouver Island ${ }^{7}$; G. primordialis, G. multinervis from Greenland ${ }^{8}$.

The Tertiary species of Ginkgo named by Unger G. adiantoides ${ }^{9}$ presents a striking agreement with the existing type, and indeed is hardly distinguishable from it ; this species has been recorded from Italy, Siberia, Scotland (Mull), and North America. Some unusually good specimens have been described by Starkie Gardner ${ }^{10}$ from the leaf-beds of the Island of Mull; one of the Mull leaves from the British Museum Collection is shown in Fig. 29, Pl. IX; the veins are very clearly marked, and in some examples traces of secretory canals may be recognized in the lamina as in Ginkgo biloba. Gardner is of opinion that 'there can be no reasonable doubt as to the specific identity of the Ardtun (Mull) fossil and the living Ginkgo biloba'; he suggests the designation G.biloba hebraidica.

\footnotetext{
1 Hartz ('96), Pl. XIX.

3 Schenk ('83).

5 Feistmantel ('79), Pl. XV.

7 Dawson ('93), Pl. VI.

9 Unger ('45), p. 2 I I.
}

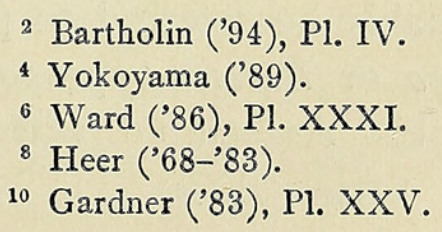




\section{I42 Seward and Gowan.-The Maidenhair}

Among other Tertiary species there are Ginkgo reniformis, described by Heer ${ }^{1}$ from Siberia ; $G$. borealis from the west coast of Greenland, and G. Laramiensis, Ward (probably identified with $G$. adiantoides), from the Laramie beds of North America ${ }^{2}$.

Flowers and seeds. The existence of Palaeozoic seeds very closely allied to those of Ginkgo has already been noticed. There is a strong probability that some at least of the Ginkgolike leaves of Palaeozoic age were borne by plants possessing no distant affinity with the recent species, but how near the relationship between the past and present types was it is impossible to decide. Our knowledge of many of the Gymnospermous seeds from Permian and Upper Carboniferous horizons is fairly complete so far as concerns their internal structure, but we have little knowledge as to the plants which bore the seeds. It would seem probable that there existed in the Permo-Carboniferous forests extinct types, such as Cordaites and other genera, which cannot be fitted into any of our existing families, but possessed certain characters, in either their vegetative or reproductive organs, which have persisted as characteristic features of the Maidenhair tree of to-day.

The recognition of certain characteristics of the Ginkgoaceae in Palaeozoic types does not by any means demonstrate the existence or even the probable existence of the family in Permian or Carboniferous times, but it is more in accordance with experience to expect that extinct genera of so remote an antiquity should exhibit points of affinity with more than one existing family. The plants which possessed characters nearest akin to those of Ginkgo were probably members of the Cordaitales, an extinct stock with which the Ginkgoaceae are closely connected.

The best examples of flowers of Mesozoic age which may reasonably be referred to plants bearing leaves of either the Ginkgo or Baiera type are those described by Heer and Schenk. Associated with the numerous Ginkgo leaves in

$$
1 \text { Heer ('68-'83). }
$$

${ }^{2}$ Ward ('86), Pl. XXXI. 
the Jurassic plant-beds of Siberia, Heer has found several specimens of male flowers which agree very closely with those of the recent species. From a central axis numerous loosely disposed stamens are given off at a wide angle, and the filaments bear two or sometimes three or more terminal pollen-sacs ${ }^{1}$. The specimen shown in Fig. 28, Pl. IX, somewhat enlarged, represents an imperfect specimen of a male flower from the Inferior Oolite beds of Yorkshire; it is less perfect than the Siberian examples, but of interest as the best so far recognized from an English locality. There is a striking similarity as regards the external form between the fossil and recent type of flower. A few isolated pollensacs of Ginkgo were figured by Phillips $^{2}$ in 1829 as 'unknown leaves'; the true nature of the fossil shown in Fig. 28 being first suggested by Nathorst.

The flowers associated with Baiera leaves and described by Schenk and other authors are similar to those of Ginkgo, but differ in the greater number of pollen-sacs borne on each stamen ${ }^{3}$.

As regards the female flowers the evidence is somewhat less conclusive. Heer has figured several fossil seeds and portions of peduncles which he refers on fairly good grounds to the genus Ginkgo, but for the most part the seeds occur as detached bodies, and throw little light on the nature of the female flowers of the Jurassic species of the Ginkgoaceae. The most interesting fossil from our present point of view is one which Carruthers described in 1869 under the name Beania gracilis ${ }^{4}$; in general structure this species is very similar to a female flower of the Cycad Zamia, in which the individual carpophylls are farther apart than in the recent type of cone. If we imagine the internodes of a Zamia flower considerably elongated, we have an arrangement closely resembling Beania. The central axis, which is fairly short and woody, bears loosely disposed secondary axes attached at right angles; these branches are probably carpophylls, and each

\footnotetext{
1 Heer ('68-'85), passim.

3 Schenk ('67).

2 Phillips ('29), Pl. VII, Fig. 23.

4 Carruthers ('69).
} 


\section{I44 Seward and Gowan.-The Maidenhair}

consists of a slender pedicel bearing two oval or subspherical seeds, with a fleshy outer coat, on the inner face of a peltate distal expansion. Schimper ${ }^{1}$, Carruthers, and other writers regard Beania as a Cycadean flower, and Potonié ${ }^{2}$ prefers the generic name Zamiostrobus to Beania as more definitely expressing the affinity. Suggestions have been made by Schimper and Saporta ${ }^{3}$ to account for the differences between Beania and typical Cycadean flowers, but these need not be discussed.

It is perhaps the most natural conclusion to draw that Beania was borne by one of the plants with pinnate Cycadean fronds, of which several species occur in the Lower Oolite strata. Our opinion, on the other hand, is that Beania does not improbably represent the female flower of a plant with leaves of the Ginkgo type and male flowers like that shown in Fig. 28, Pl. IX. This view seems to us to derive support from the following considerations. So far as we know, the Jurassic Cycadean plants possessed flowers of the Bennettites type; this has, I believe, been satisfactorily demonstrated as regards Williamsonia gigas ${ }^{4}$, and there is little doubt that the well-known fronds originally known by the name of Pterophyllum pecten were associated with the female flowers known as Williamsonia Leckenbyi, Nath. In short, we have evidence that the Cycadean stems from Jurassic and Cretaceous horizons bore flowers which differed considerably from those of recent Cycads; the evidence in support of this statement is derived from a study of English, Italian, French, German, and American specimens. We have indeed no satisfactory example of a Mesozoic Cycadean flower, constructed on the plan of the female cones of recent Cycads, which can be reasonably connected with a plant bearing Cycadean foliage.

The abundance of Ginkgo leaves in the Inferior Oolite rocks renders it probable that some trace should be found of the reproductive organs; specimens of male flowers are not very rare, and the evidence that these belong to Ginkgo or

1 Schimper ('70), p. 206.

${ }^{3}$ Saporta ('75), p. 59.
2 Potonié ('98), p. 278, Fig. 274.

4 Seward ('95), p. 146, ('97). 
Baiera, although not absolutely conclusive, is almost convincing. Heer has figured isolated seeds associated with Ginkgo leaves and a few specimens in which seeds appear to be attached to peduncles, but the examples are far from perfect. Detached seeds are not uncommon in the English Jurassic rocks, and these appear to be identical with those borne by the Beania type of flower; they are characterized by the possession of a fleshy integument which in the fossil state presents a wrinkled appearance. Beania gracilis is constructed on the same plan as the male flowers of Ginkgo, and differs from the female flowers of the recent species in the greater number of ovules and in the manner in which the ovules are attached to the peduncle. The ovules of Beania are attached to the inner side of the expanded end of each pedicel or carpophyll. If we imagine the ovules of Ginkgo turned through an angle of $180^{\circ}$ we have the collar-like envelope occupying the same position as the peltate expansion in Beania. Some of the abnormal flowers of Ginkgo, such as those figured by Fujii ${ }^{1}$ and that shown in Fig. 5, Pl. IX, approach more closely to the Beania type, and it is not improbable that these examples indicate ancestral features, as Čelakovský ${ }^{2}$ has suggested. Without wishing to overstrain such arguments as may be adduced in favour of this view, we prefer to regard Beania gracilis as a female flower, which was more probably borne by a plant belonging to the Ginkgoaceae than by a member of the true Cycadaceae.

Some isolated seeds from the London Clay of Sheppey have been doubtfully referred to Gingko under the name Ginkgo? eocenica ${ }^{3}$, but these are in themselves insufficient as evidence of the existence of the genus in the Sheppey deposits.

The records of fossil wood do not materially assist us in our review of the geological history of Ginkgo. The Tertiary wood named by Göppert Physematopitys Salisburioides ${ }^{4}$, and

\footnotetext{
${ }^{1}$ Fujii ('96).

${ }^{3}$ Gardner ('83), p. ${ }^{6}$.
}

2 Čelakovský ('90).

- Göppert ('52), p. 270. 


\section{I46 Seward and Gowan.-The Maidenhair}

regarded by him as agreeing most closely with the wood of Ginkgo, has been re-examined by Kraus and identified as the root-wood of the Cupressoxylon type ${ }^{1}$. The structure of the stem of some Palaeozoic plants ${ }^{2}$ exhibits points of resemblance to Ginkgo, but evidence of this kind leads to the same conclusion as that afforded by the Palaeozoic leaves; it demonstrates the existence of morphological features in certain synthetic or composite plant-types which are now met with in the Maidenhair tree.

\section{CONCLUSION.}

Our examination of the floral and vegetative structures of the Maidenhair tree leads us to adopt the view that this isolated type should be placed in a separate division of the Gymnosperms - the Ginkgoaceae-and no longer included in the Coniferae.

In many respects Ginkgo shows a marked affinity with the Cycads; like the extinct Cycadofilices, Ginkgo possesses both Filicinean and Cycadean characters, but while exhibiting traces of the union of Cycads and Ferns, it represents in all probability a very ancient type which may have been merged into the Cordaitales in the Palaeozoic era. Among the numerous features in which Ginkgo resembles the Cycadaceae, the most striking are recognized in the ovules and seeds, in the production of spermatozoids, and in certain anatomical characters referred to in the above description of the reproductive and vegetative organs.

The records of the rocks demonstrate both the antiquity and wide geographical range of Ginkgo and allied forms during the Mesozoic and Tertiary periods; species of Ginkgo and Baiera have been discovered in almost all parts of the world. The majority of the older representatives of the Ginkgoaceae agree more closely with the genus Baiera; in the Jurassic, Cretaceous, and Tertiary periods, Ginkgo itself

${ }^{1}$ Kraus ('86), p. 75.

${ }^{2}$ e.g. Dadoxylon Pedroi, Zeill., from Permo-Carboniferous rocks of Brazil. Vide Zeiller ('95). 


$$
\text { Tree (Ginkgo biloba, L.). }
$$

appears to have been especially abundant in more northern latitudes, whence it may have gradually retreated to escape from unfavourable climatic conditions.

It is sometimes stated that the more deeply-lobed leaves of the Maidenhair tree recall most vividly the ancient forms; this statement, while in the main supported by palaeontological evidence, must not be made without reserve. Leaves with an entire lamina are occasionally met with in Jurassic strata (Pl. X, Fig. 54); both forms of leaf were represented, though on the whole the species with more numerous and narrower segments predominated. 


\section{Seward and Gowan.-The Maidenhair}

\section{BIBLIOGRAPHY.}

Archangeli, G., '95 : La Collezione del Cav. S. de Bosniaski, \&c., Bull. Soc. Bot. Ital., I 895, p. 237 .

BaIley, L. H., '96 : The Survival of the Unlike. New York, 1896.

BARTHOLIN, C. T., '94 : Nogle i den Bornholmske Juraformation forekommende Planteforsteninger, Bot. Tidssk., xix, p. 87 .

Beddome, R. H., '65 : The Ferns of British India. Madras, I865-70.

BelajefF, W., '97 : Ueber den Nebenkern in spermatogenen Zellen und die Spermatogenese bei den Farnkräutern, Ber. deutsch. Bot. Ges., vol. xv, p. 337 .

Bertrand, C. E., '74: Anatomie comparée des tiges et des feuilles chez les Gnétacées et les Conifères.

'78: Étude sur les téguments séminaux des végétaux phanérogames gymnospermes, Ann. Sci. Nat., vii (6), p. 57 .

BIRD, I. L., '80 : Unbeaten Tracks in Japan. London, I 880.

BraUn, F., '43 : In Graf zu Münster's Beiträge zur Petrefactenkunde, Heft vi, Bayreuth.

'75: Die Frage nach der Gymnospermie der Cycadeen, erläutert durch die Stellung dieser Familie im Stufengang des Gewächsreiches, Monats. k. preuss. Akad. Wiss., p. $24 \mathrm{I}$.

Brongniart, A., '28: Histoire des végétaux fossiles. Paris, I 828.

'81: Recherches sur les graines fossiles silicifiées. Paris, I88I.

Bunge, A., '31 : Enumeratio Plantarum quas in China boreali collegit.

Capellini, G., e Solms-Laubach, Graf ZU, '91: I Tronchi di Bennettitee dei Musei italiani, Mem. Acc. Sci. Inst., Bologna (5), ii, p. I6I.

CARrière, E. A., '67 : Traité général des Conifères. Paris, I867.

Carruthers, W., '67 : On some Cycadean Fruits from the Secondary Rocks of Britain, Geol. Mag., iv, p. IoI.

Čelakovský, L., '90 : Die Gymnospermen, Abh. k. böhm. Ges. Wiss., iv (vii), p. I.

Clarke, C. B., '90: On the Plants of Kohmia and Muneypore, Linn. Journ., xxv, p. I.

Сонn, F., '96 : Die Pflanze, vol. i, Breslau.

Dawson, J. W., '85: On the Mesozoic Floras of the Rocky Mountain Region of Canada, Trans. R. Soc. Canada, I885.

'93 : On new Species of Cretaceous Plants from Vancouver Island, ibid., 1893, p. 53 .

Dippel, L., '62 : Zur Histologie der Coniferen, Bot. Zeit., I862, p. I 70.

'63: Ibid., I863, p. 253.

DRUDE, O., '79: In Schenk's Handbuch, vol. i, p. 654 .

DUNKer, W., '46: Monographie der norddeutschen Wealdenbildung. Braunschweig, I846.

Eichler, A. W., '52 : In Martius' Flora Brasiliensis, vol. iv, p. 409.

'73 : Sind die Coniferen gymnosperm oder nicht? Flora, I873,

p. $24 \mathrm{I}$.

'89: In Engler and Prantl, Die nat. Pflanz., Teil ii, p. 108. 
Eichwald, E., '68 : Lethaea Rossica. Stuttgart, I868.

Endlicher, S., '36: Genera Plantarum. Vindobonae, 1836-40.

47 : Synopsis Coniferarum. Sangalli, 1847 .

Engler, A., '97 : In Engler and Prantl, Die nat. Pflanz., Nachtrag zu Teile ii-iv, p. 19.

Essner, B., '86: Ueber den diagnostischen Werth der Anzahl und Höhe der Markstrahlen bei den Coniferen, Abh. naturf. Ges. Halle, xvi, p. I.

EtTingshausen, C., und Krasan, F., '90: Untersuchungen über Ontogenie und Phylogenie der Pflanzen, Denk. k. Akad. Wiss., Wien.

Fankhauser, J., '82 : Entwicklung des Stengels und Blattes von Ginkgo. Bern, 1882.

Feistmantel, O., '89 : Uebersichtliche Darstellung der geologisch-palaeontologischen Verhältnisse Süd-Afrikas, Abh. k. böhm. Ges. Wiss. (vii) iii.

vol. i, P1. 4. 79 : Outlines of the Madras Coast, Mem. Geol. Surv., India,

FELIX, J., '94 : Untersuchungen über fossile Hölzer, Zeitsch. deutsch. Geol. Ges., Heft I, p. 79.

FLORE DES SERRES, '54: Paris, 1854 .

Fontaine, W. M., ' 83 : Contributions to the Knowledge of the older Mesozoic Flora of Virginia, U. S. Geol. Surv., Monographs, vol. vi, I883.

and White, I. C., ' 80 : The Permian or Upper Carboniferous Flora of West Virginia and South-west Pennsylvania, Second Geol. Surv., Penns., I 880.

Fortune, R., '47 : Three Years' Wanderings in the Northern Provinces of China. London, 1847 .

- '63: Yedo and Peking, a Narrative of a Journey to the Capitals of Japan and China. London, 1863 .

FujII, K.,' 96 : On the different Views hitherto proposed regarding the Morphology of the Flowers of Ginkgo biloba L., Bot. Mag. Tokyo, x, p. 7 .

Gardeners' Chronicle, '99 : The Maidenhair Tree, p. 467, I899.

Gardner, J. S., '83: A Monograph of the British Eocene Flora, Pal. Soc., I $883-86$.

Geyler, -,'67 : Ueber den Gefässbündelverlauf in den Laubblattregionen der Coniferen, Pringsh. Jahrb. vi, p. I 8 .

GoEbeL, K., '81 : Beiträge zur vergleichenden Entwickelungsgeschichte der Sporangien, Bot. Zeit. I88I.

Goeppert, H. R., '50 : Monographie der fossilen Coniferen. Leiden, I850. und Menge, '83 : Die Flora des Bernsteins, vol. i. Danzig, i 883.

Gouan, A., '12 : Description du Ginkgo biloba, dit noyer du Japan. Montpellier, I8I 2.

Grand'Eury, C., '77 : Flore Carbonifère du Dép. de la Loire. Paris, 1877.

Haberlandt, G., '96 : Physiologische Pflanzenanatomie. Leipzig, I896.

Hartig, T., '48: Beiträge zur Geschichte der Pflanzen und zur Kenntniss der norddeutschen Braunkohlen-Flora, Bot. Zeit., 1848, p. I 22.

Hartz, N., '96: Planteforsteninger fra Cap Stewart i Ostgronland, Medd. Gronland, vol. xix, p. 217 .

Heer, O., '76 : Flora fossilis Helvetiae. Zurich, 1876.

'68-83: Flora fossilis Arctica, 7 vols.

'81: Zur Geschichte der Ginkgo-artigen Bäume, Bot. Jahrb., vol. i. 


\section{I50 Seward and Gowan.-The Maidenhair}

Henckel, J. B., und Hochstetter, W., '65 : Synopsis der Nadelhölzer

Hirase, S.,' 94: The Fecundation Period of Ginkgo, Bot. Mag., Tokyo.

'95: Études sur la fécondation et l'embryogénie du Ginkgo biloba, Journ.

Coll. Sci., Imp. Univ. Japan, vol. viii.

'97: Untersuchungen über das Verhalten des Pollens von Ginkgo biloba,

Bot. Cent., vol. xlix, p. 33 .

'98: Études sur la fécondation et l'embryogénie du Ginkgo biloba, Journ.

Coll. Sci. Japan, vol. xii, p. I०з.

Hofmeister, W.,' 63 : On the Germination, Development, and Fructification of the higher Cryptogamia. London, I 863 .

HöHNEL, F. von, '77: Ueber den Kork und verkorkte Gewebe überhaupt, Sitz.

K. Akad. Wiss. Wien, lxxvi, Abt. i, p. 507.

HookeR, IV. J., '42 : Icones Plantarum.

'46: Species Filium.

'57: On Asplenium (Shaffneria) nigripes, Hooker's Journ. Bot., ix, p. 268.

Hooker, J. D., and Binney, E. W., '55: On the Structure of certain Limestone Nodules enclosed in Seams of Bituminous Coal, \&c., Phil. Trans. R. Soc., I 855 , p. I 49 .

Ikeno, S., '98: Zur Kenntniss des sog. centrosomähnlichen Körpers im Pollenschlauch der Cycadeen, Flora, vol. 85 , p. ${ }_{5}$.

JACQUin, N. J. von, '19 : Ueber den Ginkgo, Jahrb. Med. Oest. I8I9.

Kaempfer, E., 1712 : Amoenitates Exoticae. Lemgoviae, I $7 \mathbf{I} 2$. 1727 : History of Japan.

Knowlton, F. H., '93 : Fossil Flora of Alaska, Bull. Geol. Soc. Am., vol. 5 .

KraUs, G., '64: Mikroskopische Untersuchungen über den Bau lebender und vorweltlicher Nadelhölzer, Würzb. Nat. Zeitsch., v.

'86 : Zur Diagnostik des Coniferenholzes, Abh. Naturf.-Ges. Halle, xvi, p. 92 .

KuRtz, F., '94: Sobre la Existencia del Gondwana inferior en la República Argentina, Revist. Mus. de la Plata, vol. vi, p. I25.

Lesquereux, L., '79 : Atlas to the Coal Flora of Pennsylvania. Harrisburg, 1879.

Lima, W. DE, '88: Flora Fossil de Portugal. Lisbon, I888.

Lindley, J., and Hutton, W., '31-'37 : The Fossil Flora of Great Britain, 3 vols., London.

Linnaeus, C. A., 1771 : Mantissa Plantarum. Holmiae, I771.

Loudon, J. C., '75 : Trees and Shrubs. London, 1875.

Marion, A. F., '90: Sur le Gomphostrobus heterophylla, Compt. rend., Paris, I89o, vol. cx.

Massalongo, E. G., '59 : Studii sulla flora fossile e geologia stratigrafica del Senigalliese. Imola, 1859 .

Masters, M. T., '91: Review of some Points in the Comparative Morphology, Anatomy, and Life-history of the Coniferae, Journ. Linn. Soc. xxvii, p. 226.

Matsumura, J., '84: Nippon Shokubutsumeii, Nomenclature of Japanese Plants in Latin, Japanese, and Chinese. Tokio, I884.

Moelle R, J., '82 : Anatomie der Baumrinden. Berlin, I882.

MoHL, H. von, '32 : Ueber den Bau des Cycadeen-Stammes und sein Verhältniss $z \mathfrak{u}$ dem Stamme der Coniferen und Baumfarn, 1832.

NAKAMURA, Y., '83: Ueber den anatomischen Bau des Holzes der wichtigsten japonischen Coniferen, Unt. forst. Bot. Inst., München, iii. 
Nathorst, A. G., '78: Om Ginkgo ? crenata Brauns sp., Öfver. K. Vet.-Akad. Förh., p. 8r.

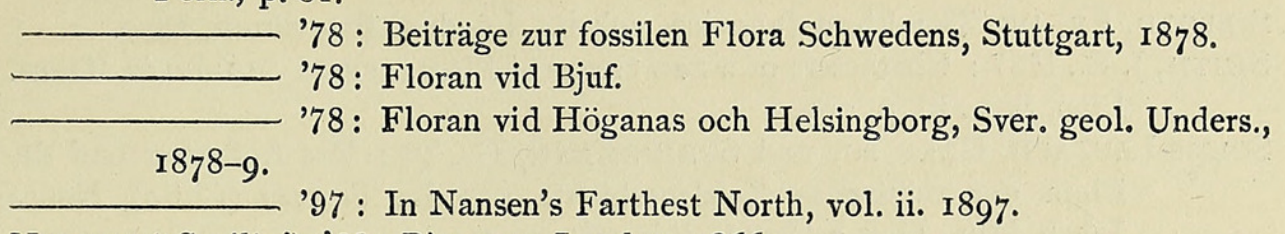

NELSON ('Senilis'), '66 : Pinaceae, London, I866.

Newberry, J. S., '91: The Flora of the Great Falls Coal-field, Montana, Amer. Journ. Sci., vol. xli.

Newton, E. T., and Teall, J. J. H., 97 : Notes on a Collection of Rocks and Fossils from Franz Josef Land, Quart. Journ. Geol. Soc., vols. i-iii, p. 477.

Nicholson, E., '92 : Conifers as Specimen Trees and for Landscape Gardening, Journ. R. Hort. Soc. xiv, p. 34 .

PAX, F., '90 : Allgemeine Morphologie der Pflanzen.

Penzig, O., '94 : Pflanzenteratologie, vol. ii, Genua.

PhILliPs, J., '29 : Illustrations of the Geology of Yorkshire. York, I829.

PotoniÉ, H., '93 : Die Flora des Rothliegenden von Thüringen, Abh. k. preuss. geol. Landes, Berlin, Heft ix.

'98: Lehrbuch der Pflanzenpalaeontologie. Berlin, I899.

Ratte, F., '87 : Notes on some Australian Fossils, I. Salisburia palmata, Proc. Linn. Soc., N. S. Wales, ii, p. I 36.

Renault, B., '96: Bassin Houiller et Permien d'Autun et d'Épinac. Paris, 1896. '96: Notice sur les travaux scientifiques. Autun, I 896.

Richard, L. C., '26 : Commentatio Botanica de Coniferis et Cycadeis. Stuttgart, I 826 .

Rothert, W., '99: Ueber parenchymatische Tracheïden und Harzgänge im Mark von Cephalotaxus-Arten., Ber. deutsch. Bot. Ges. xvii, p. 275.

Russow, E., '83 : Zur Kenntniss des Holzes, insonderheit des Coniferenholzes, Bot. Cent. xiii, p. 29.

Saporta, Le Marquis De, '75: Plantes Jurassiques, Tome ii, Cycadées. '84: Tome iii, Conifères.

et MARION, '85: L'Évolution du règne végétal, vol. i. Paris, I 885.

Schenk, A., '67: Die fossile Flora der Grenzschichten des Keupers und Lias Frankens. Wiesbaden, I867.

'71: Die Flora der nordwestdentschen Wealdenformation. Palaeontograph. vol. xix, p. 203 .

'83: In Richthofen's China, vol. iv. Berlin, I883.

'87 : Fossile Pflanzen aus der Albourskette, Bibl. Bot., Heft vi, 1887 .

Schimper, W. P., '70: Traité de paléontologie végétale, vol. ii, 1870-72.

Schmalhausen, J., '79 : Beiträge zur Jura-Flora Russlands, Mém. Acad. Imp. Sci., St.-Pétersbourg (7), xxvii.

Schulz, P., '83: Das Markstrahlengewebe und seine Beziehungen zu den leitenden Elementen des Holzes, Jahrb. k. Bot. Gart. Berlin, ii, p. 2 Io.

Scotт, D. H., '96 : Address to Section K, Brit. Assoc. Report, I896, p. 992, Liverpool.

Seward, A. C., '95: The Wealden Flora, Pt. ii. Brit. Mus. Catalogue. London, 1895. '97: On the Leaves of Bennettites, Proc. Phil. Soc. Cambridge, vol. ix, p. 273 . 


\section{I52 Seward and Gowan.-The Maidenhair}

Shirley, J., '98: Additions to the Fossil Flora of Queensland, Geol. Surv. Bull., No. 7. Brisbane, 1898 .

Siebold, Fr. DE, '70: Flora Japonica, vol. ii. Lugduni Batavorum, i87o.

Smith, J. E., 1797 : Characters of a new Genus of Plants named Salisburia, Trans. Linn. Soc., iii, p. 33 .

Solms-Laubach, Graf zu, und Steinemann, G., '99 : Das Auftreten und die Flora der rhätischen Kohlenschichte von La Ternera (Chile), Neues Jahrb. Min., Heft 3 (Beibl., Bd. xii), p. 593.

SpACH, E., '42: Histoire naturelle des végétaux, vol. xi. Paris, 1842.

Strasburger, E., '72: Die Coniferen und die Gnetaceen. Jena, 1872.

'79: Die Angiospermen und die Gymnospermen. Jena, 1879.

I 882 .

'82: Ueber den Bau und das Wachsthum der Zellhäute. Jena, '92 : Histologische Beiträge, iv.

Thiвout, E., '96: Recherches sur l'appareil mâle des Gymnospermes. Lille, i 896.

Thомаs, F., '65: Zur vergleichenden Anatomie der Coniferen-Laubblätter, Pringsh. Jahrb. iv, p. 23.

Thunberg, C. P., 1784 : Flora Japonica, Lipsiae, 1784.

Tieghem, Ph. van, '69: Anatomie comparée de la fleur femelle et du fruit des Cycadées, des Conifères et des Gnétacées, Ann. Sci. Nat. (5) x, p. 269. '70: Recherches sur la symétrie de structure des plantes vasculaires, Ann. Sci. Nat. (5) xiii, p. I. '87 : Sur le second bois primaire de la racine, Bull. Soc. Bot. xxxiv, p. IOI.

'91: Traité de Botanique. Paris, I891.

et Douliot, H., ' 88 : Recherches comparatives sur l'origine des membres endogènes dans les plantes vasculaires, Ann. Sci. Nat. (7) viii, p. I.

Treub, M., '84 : Recherches sur les Cycadées, Ann. Bot. Jard., vol. ii, p. 32.

Tubeuf, K. von, '91: Samen, Früchte und Keimlinge der in Deutschland heimischen oder eingeführten förstlichen Culturpflanzen. Berlin, $\mathbf{1} 89 \mathrm{I}$.

Unger, F., '45 : Synopsis plantarum fossilium. Lipsiae, 1845 .

WARD, L. F., '86 : Synopsis of the Flora of the Laramie Group, U.S. Geol. Surv., 6th Ann. Rep.

Watson, P. W., '25 : Dendrologia Britannica, vol. ii, London. W., '98: Scolopendrium nigripes, Gard. Chron. xxiv, p. 333 .

Webber, H. J., 97 : Notes on the Fecundation of Zamia and the Pollen-tube Apparatus of Ginkgo.

Wieland, G. R., '99 : A Study of some American Fossil Cycads, Pt. III, Amer. Journ. Sci., vol. vii, p. $3^{83}$.

Williamson, W. C., '77 : On the Organization of the Fossil Plants of the CoalMeasures, Pt. viii, Phil. Trans. I877, p. 2 I 3.

' 83 : Ibid., Phil. Trans. I883, p. 459.

Worsdell, W. C., '97 : On Transfusion Tissue, Trans. Linn. Soc. (2), v, p. zor.

Yoxoyama, M., '89: Jurassic Plants from Kaga, Hida, and Echizen, Journ. Coll. Sci. Imp. Univ. Japan, vol. iii, pt. i.

ZeIller, R., '92: Études sur la flore fossile des dépôts Houillers et Permiens des environs de Brive. Paris, I 897 .

'95: Note sur la flore fossile des Gisements houillers de Rio Grande do Sul, Bull. Soc. Géol. France, vol. xxiii [3], p. 6or, 1895 . 
Zimmermann, A., '80 : Ueber das Transfusionsgewebe, Flora, I88o, p. 2.

Zuccarini, J. G., '40 : Beiträge zur Morphologie der Coniferen, Abh. Bay. Akad. Wiss., iii, p. 753.

\section{EXPLANATION OF FIGURES IN PLATES VIII, IX, AND X.}

Illustrating the paper by Mr. Seward and Miss Gowan on the Maidenhair Tree.

\section{PLATE VIII.}

Photograph of a water-colour painting of Ginkgo biloba, by a Chinese artist.

(Photographed by Mr. Edwin Wilson from the original sketch in the possession of Mrs. Robb.)

\section{PLATE IX.}

Fig. I. Abnormal female flower with five small ovules (nat. size).

Figs. 2, 3. Abnormal female flower with three ovules and a bud $b$ (nat. size).

Fig. 4. Abnormal female flower; $b$, leaf-scar (nat. size).

Fig. 5. Abnormal female flower (nat. size).

Fig. 6. Female flower with two large ovules (nat. size).

Fig. 7. Four pollen-sacs attached to one filament (slightly enlarged).

Fig. 8. Male flower; $b$, bract (nat. size).

Fig. 9. A single stamen showing two open pollen-sacs (slightly enlarged).

Fig. Io. A short shoot cut in half longitudinally, showing an irregularly ' discoid pith' (slightly enlarged).

Figs. II-23. Diagrams illustrating the position and number of vascular bundles in the abnormal flowers shown in Figs. I-4.

Figs. 24-27. Diagrams illustrating the connexion between the double leaf-trace and the stele of a long shoot of Ginkgo. $s=$ group of secretory cells.

Fig. 28. Part of a male flower of a fossil Ginkgo from the Inferior Oolite of Gristhorpe Bay, near Scarborough (slightly enlarged. Leckenby collection, Cambridge).

Fig. 29. Ginkgo adiantoides from the Eocene leaf-beds of Mull (nat. size. British Museum).

Fig. 3o. Scolopendrium nigripes. Half of a leaf, showing the veins and sori (nat. size. Botanic Garden, Cambridge).

Figs. 3I-37. Scale-leaves and young foliage-leaf from the terminal bud of a long shoot (slightly enlarged).

Fig. 38. Two small leaves borne on the stem of a seedling (slightly enlarged).

Figs. 39-4I. Scale-leaf and young foliage-leaves. $h=$ hairs (slightly enlarged).

Fig. 42. Branched short shoot (nat. size).

Fig. 43. The endosperm of a fallen seed in median longitudinal section. $a=$ archegonium ; $a^{\prime}=$ embryo (nat. size). 


\section{Seward and Gowan.-The Maidenhair Tree.}

Fig. 44. Embryo separated from the endosperm (nat. size).

Fig. 45. Seed of Ginkgo, showing the woody testa $b$, the endosperm $d$, and the remains of the nucellus $c$ (nat. size).

Fig. 46. Ginkgo digitata, from the Inferior Oolite (nat. size. Manchester Museum).

Fig. 47. A young ovule in median longitudinal section. $i=$ integument; $p c=$ pollen-chamber $; e=$ young embryo-sac (slightly enlarged).

Fig. 48. Apical view of the endosperm of a fallen seed showing two archegonia, $a, a$ (slightly enlarged).

\section{PLATE X.}

Fig. 49. Tangential section through the autumn wood of a branch.

Fig. 50. Transverse section of the filament of a stamen. $p x=$ protoxylem; $c p=$ centripetal xylem; $t s=$ transfusion tracheids.

Fig. 5I. Transverse section of a young primary shoot. $e=$ endodermis.

Fig. 52. Longitudinal section through the phloem of a branch.

Fig. 53. Transverse section through part of the stele of a short shoot. It $=$ double leaf-trace.

Fig. 54. Ginkgo digitata, from the Inferior Oolite near Scarborough (slightly reduced. York Museum).

Fig. 55. Transverse section of the root of a seedling.

Fig. 56. Multicellular hairs from the petiole of a scale-leaf.

Fig. 57. Radial longitudinal section through the secondary xylem of a branch showing tracheids and medullary-ray cells.

Fig. 58. Transverse section of a portion of the xylem of a short shoot.

Fig. 59. Tangential section through the cortex of a short shoot. $x$ =group of tracheids.

Fig. 6o. Schizaea dichotoma, Siv. (slightly enlarged. The Herbarium, Cambridge).

Fig. 6I. Modified foliage-leaf of Ginkgo biloba bearing a marginal ovule (after Fujii).

Figs. 62-66. Leaves of Ginkgo biloba.

Fig. 67. Actinopteris radiata, Link (nat. size).

Fig. 68. Baiera gracilis, Bunb., from the Inferior Oolite of Yorkshire (British Museum) (nat. size).

Fig. 69. Ginkgo sp., from Eyeford (slightly reduced. Cirencester Museum).

Fig. 70. Leaf of Ginkgo biloba. 
Annals of Botany.

Vol.XIV. PL.VIII.

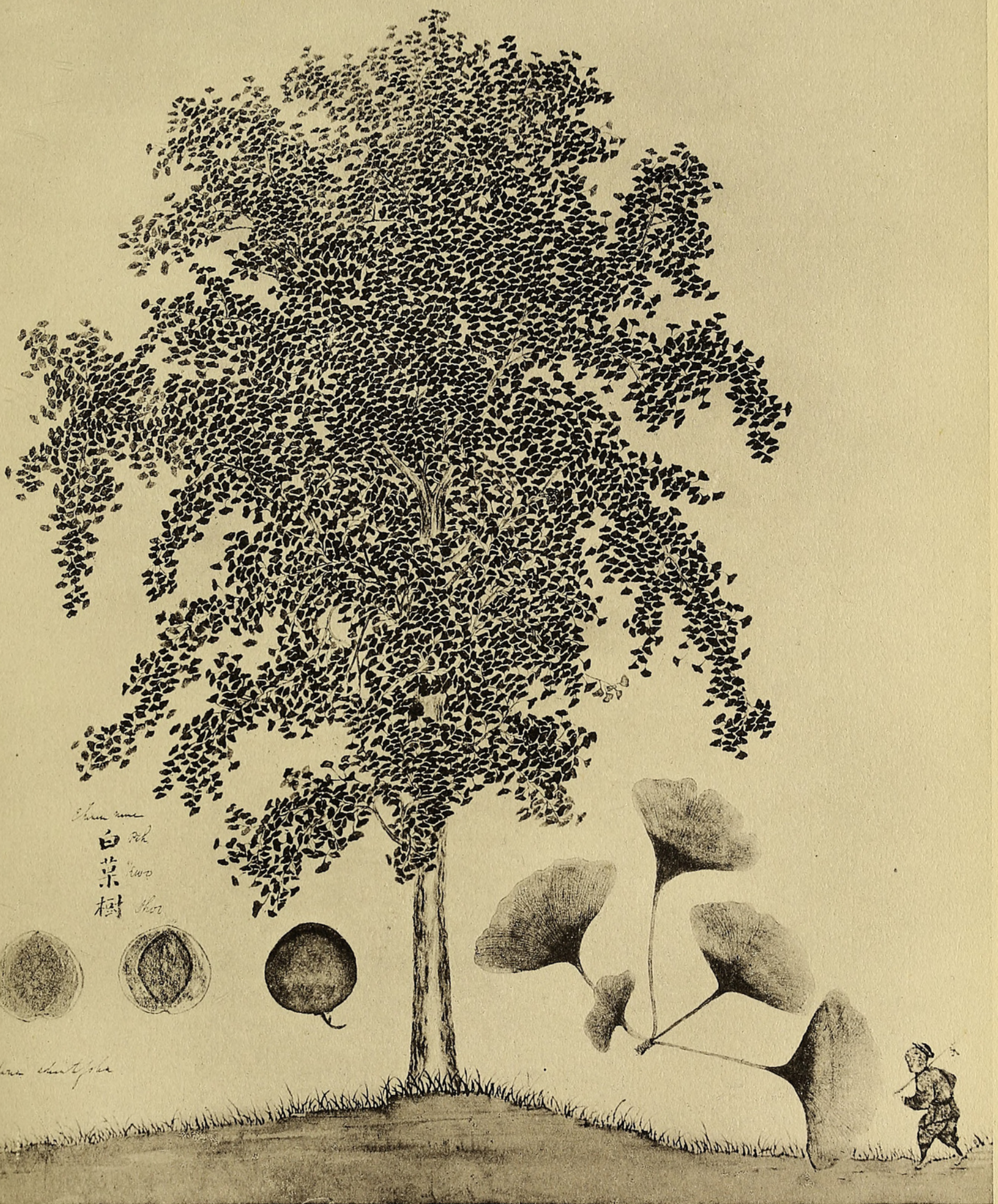


Annals of Botany

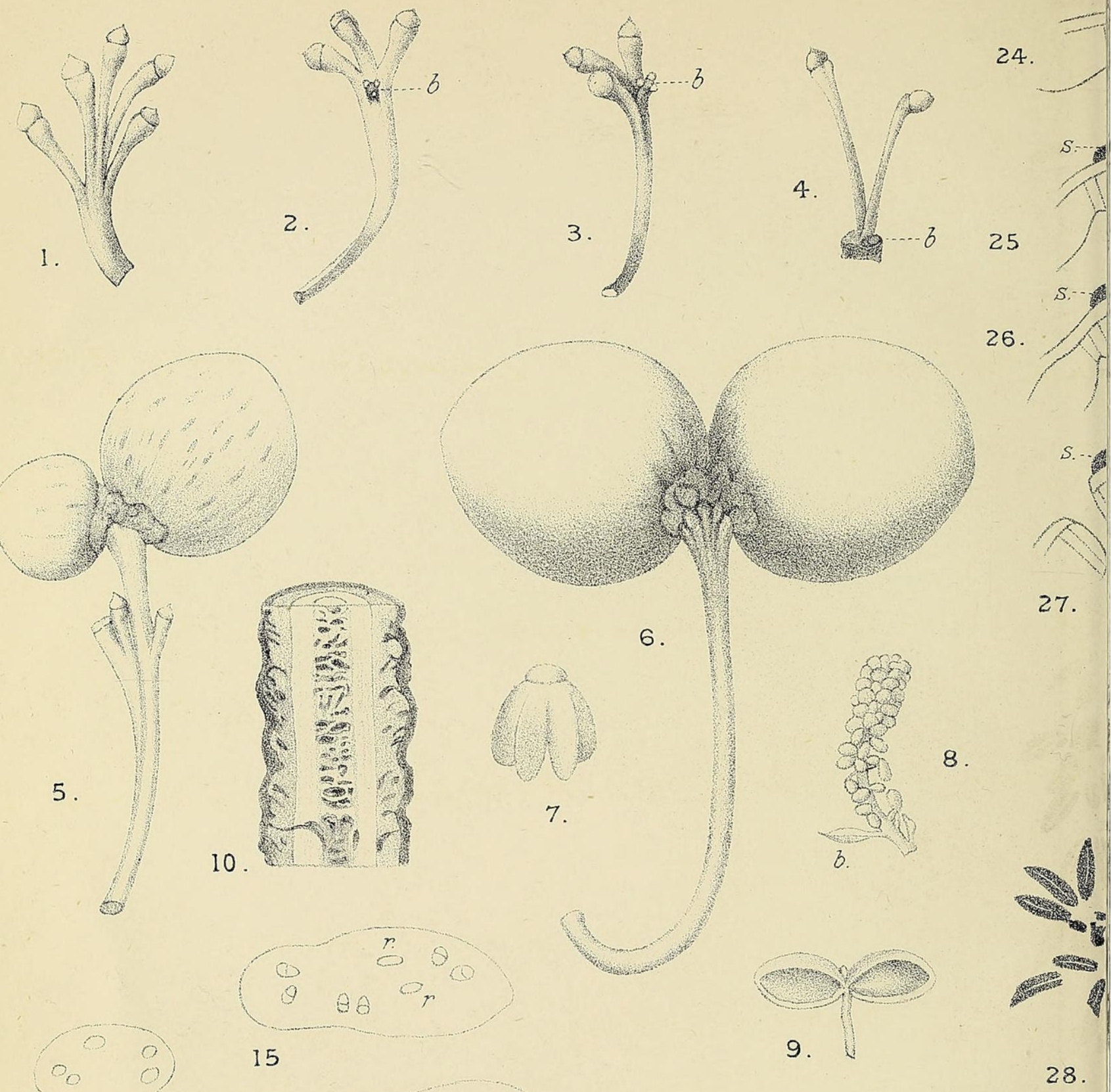

11.
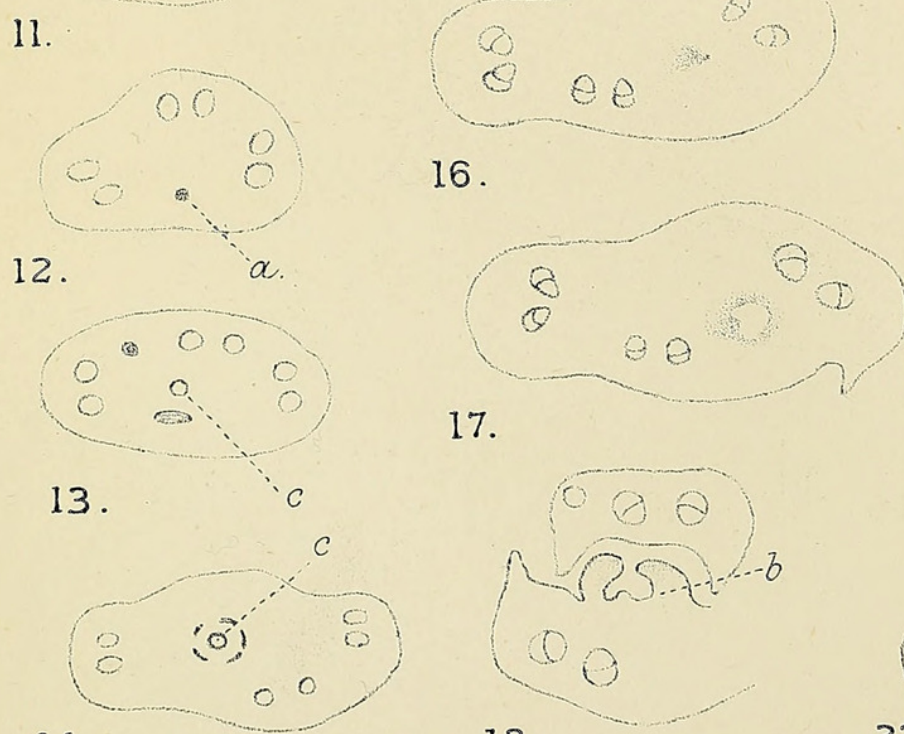

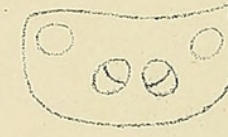

19
17.

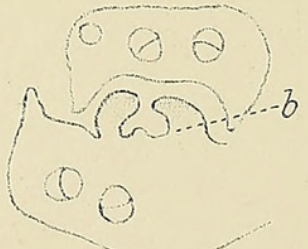

18.

$S E W A R D$

\& GOWAN $N$ - $O N$ G I K $\mathrm{N} O$ 
VoL XIV, PU.LX.
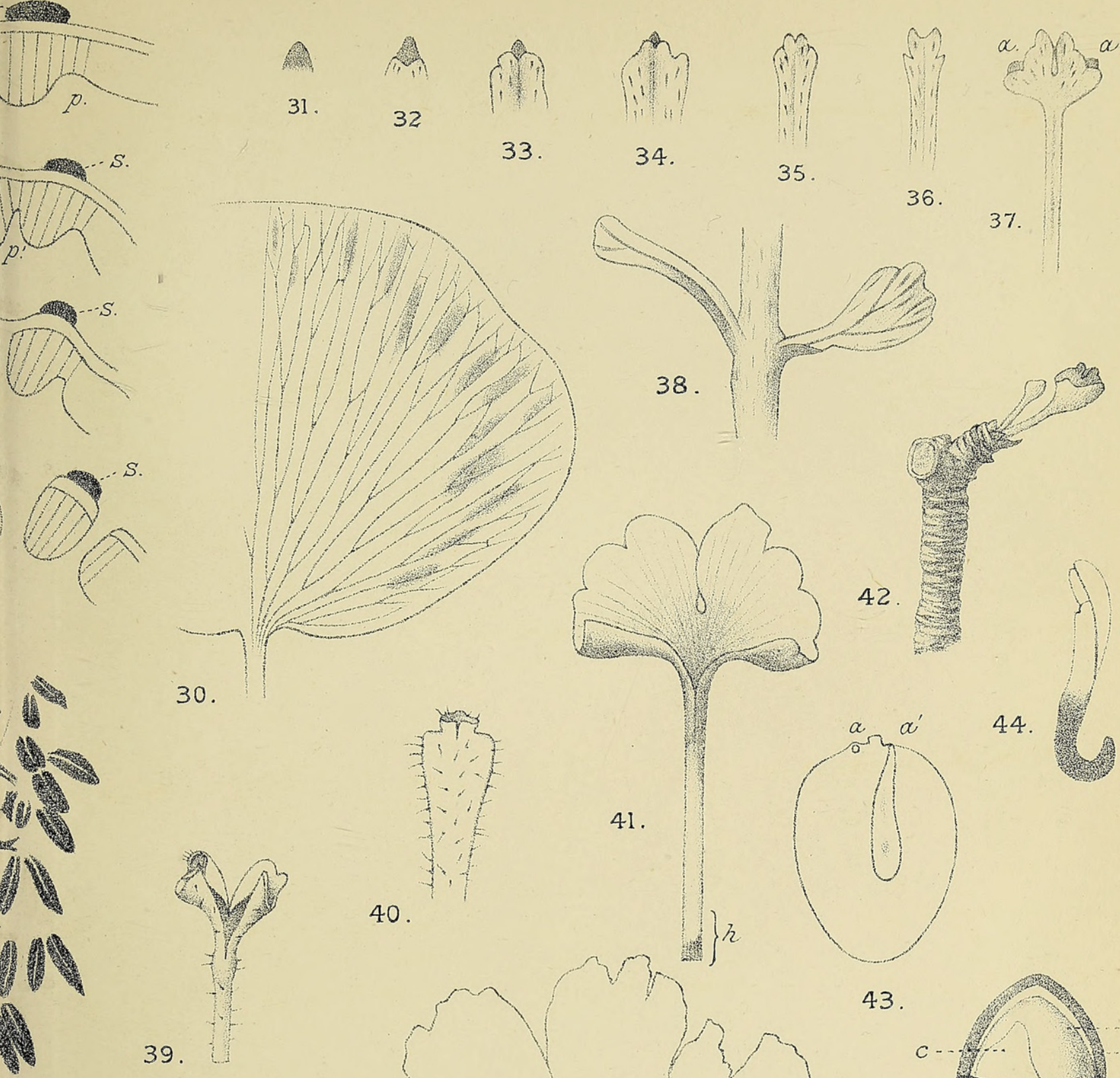

30.
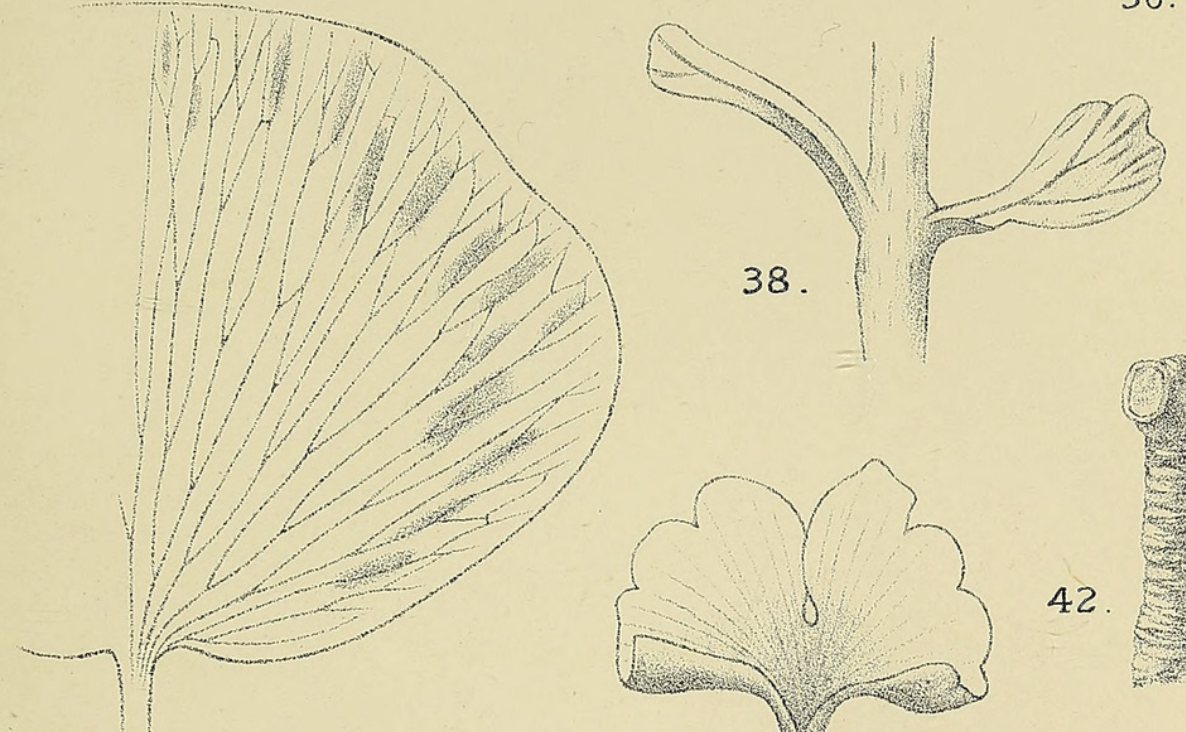

37.
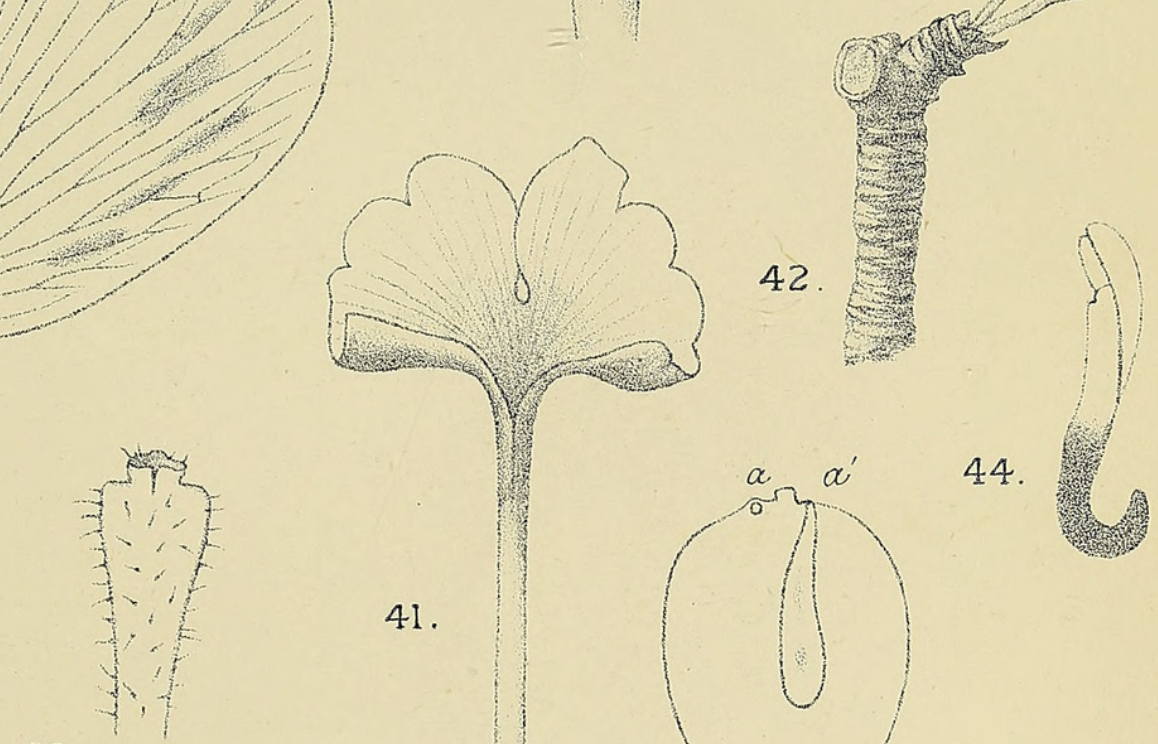

41.

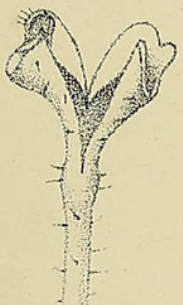

39.
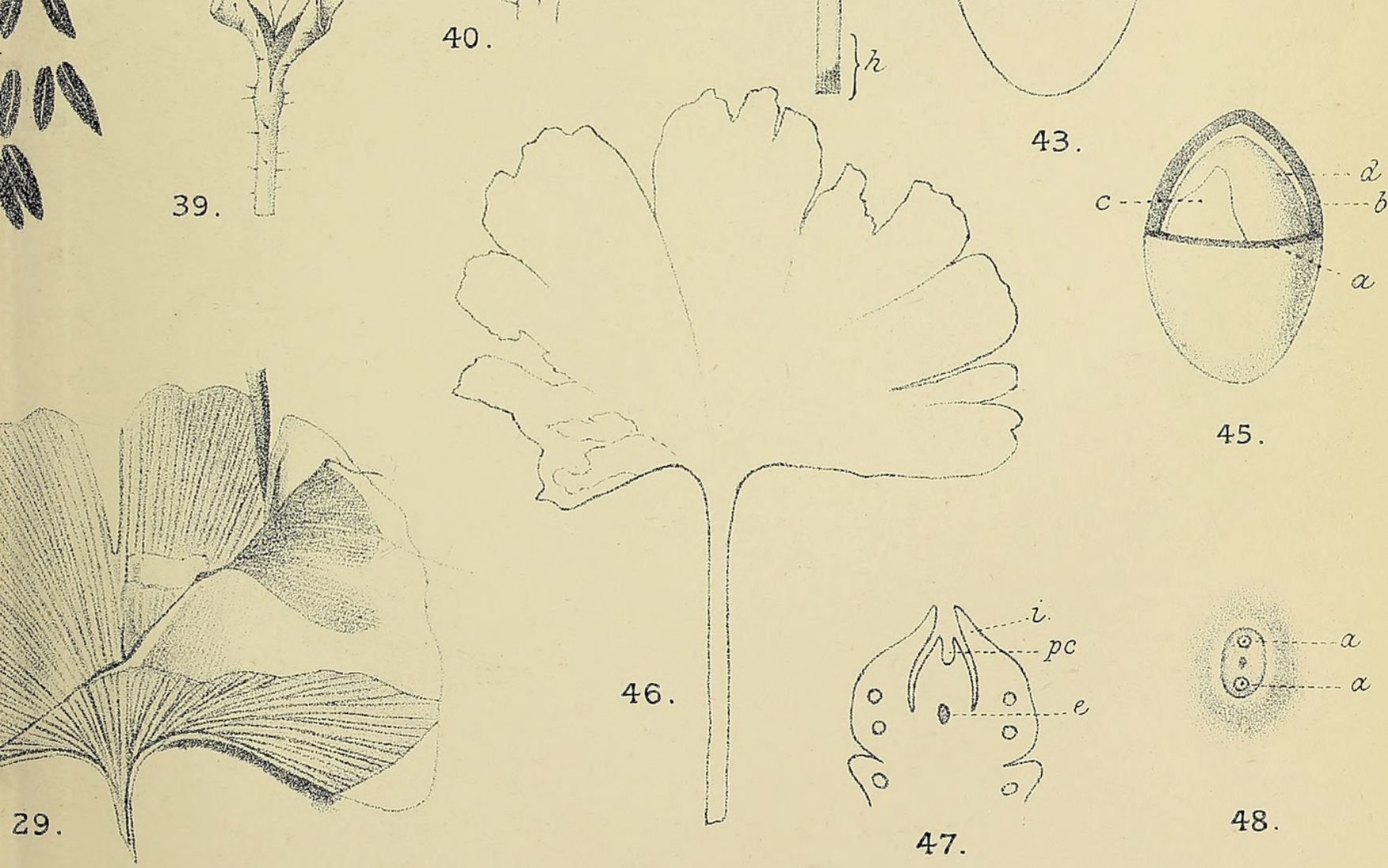
Annals of Botany
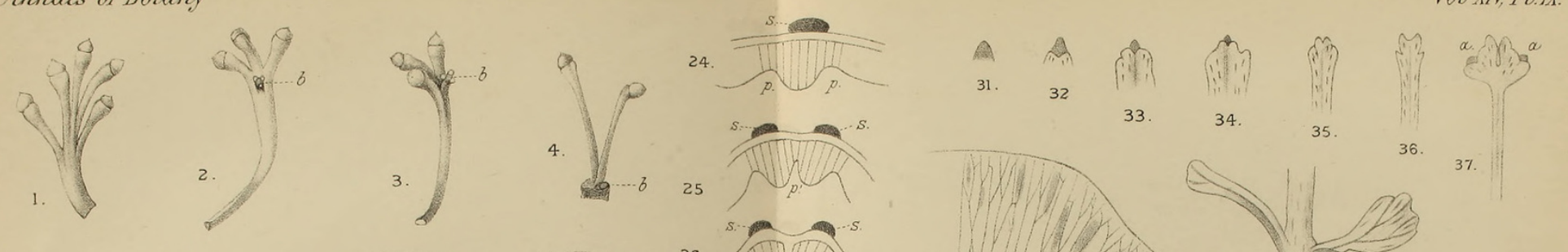

Vol XIV, PL.IX.
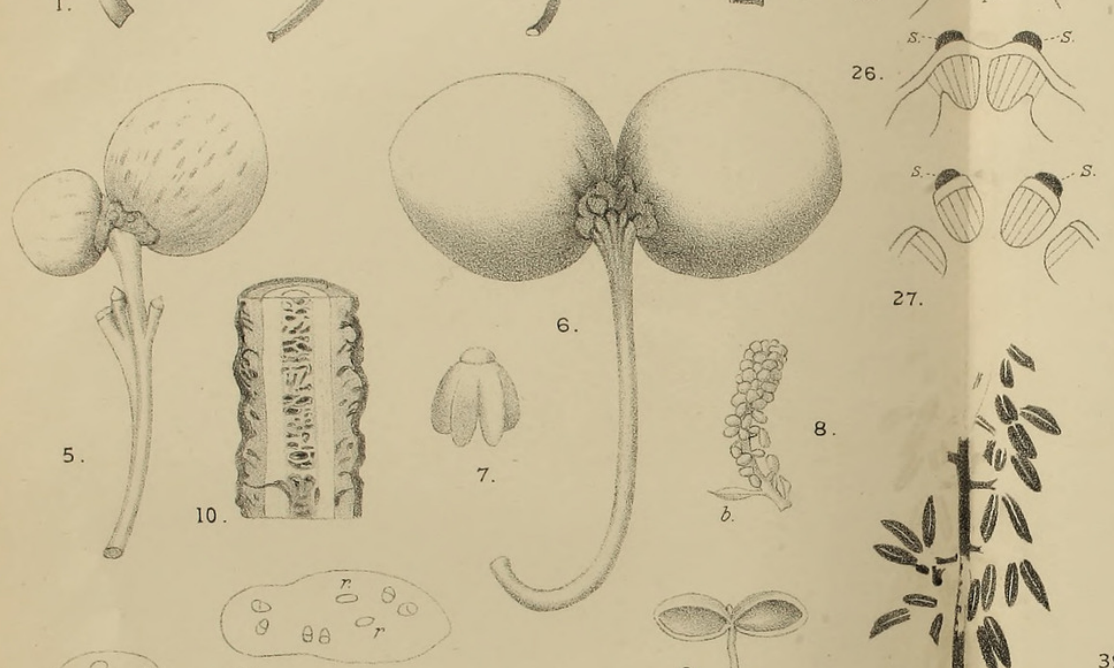

$$
\begin{array}{ll}
0 & 0 \\
0 & 0
\end{array}
$$

$$
\begin{aligned}
& 11 . \\
& \text { 12. } \begin{array}{lll}
a & a \\
0 & 0 & 0 \\
0 & 0 & 0
\end{array}
\end{aligned}
$$
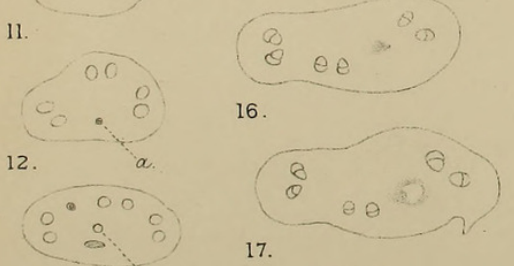

$$
13 .
$$

J. Gowan del.
$(08)$

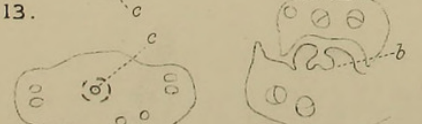
18. $\left(\begin{array}{ll}0 & 0 \\ 0 & 0\end{array}\right)$ 22.
6.
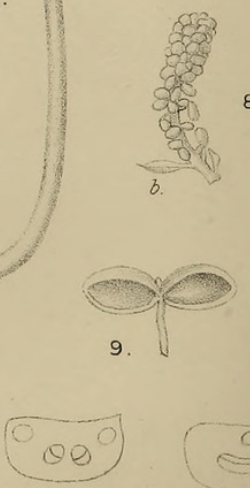

19

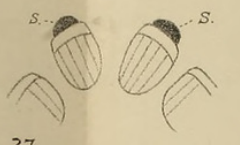

27.

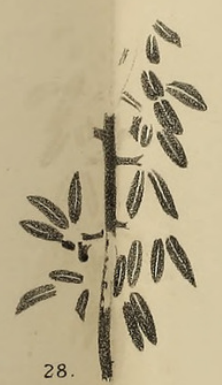

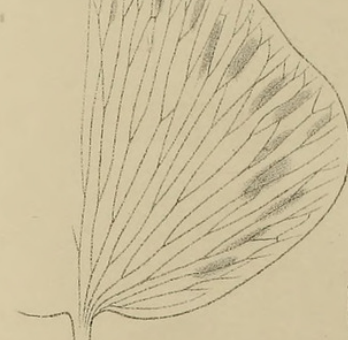

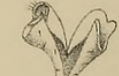

30.

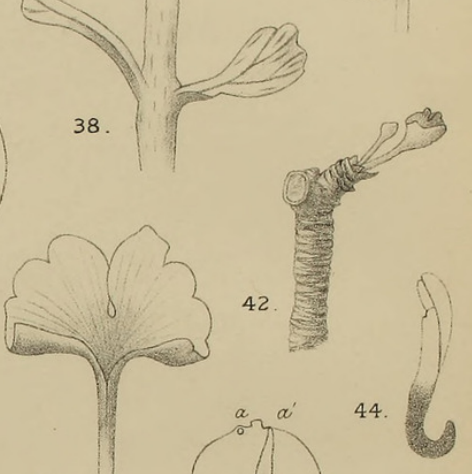

39.

21.

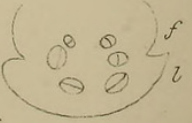

(2) 23.
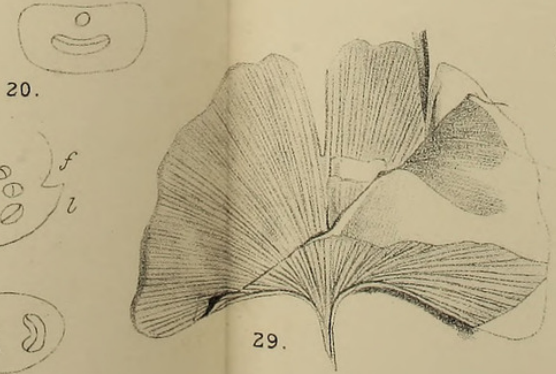

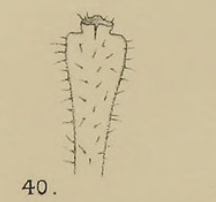

41.

1. d)

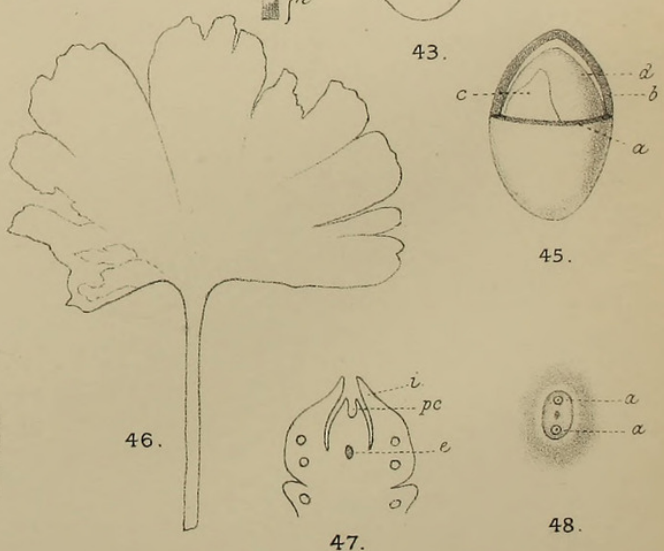

47 
Annals of Botany
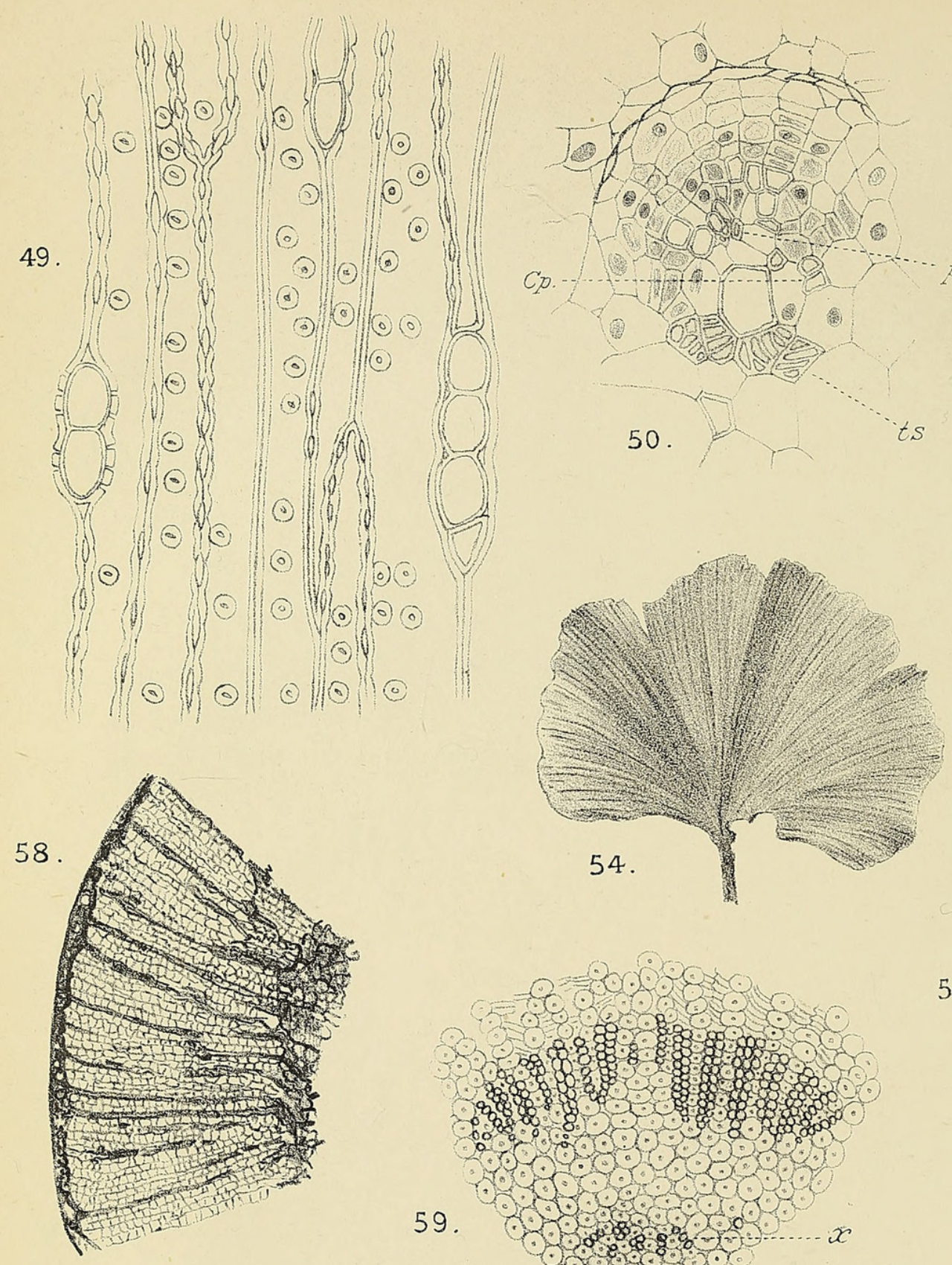

51.
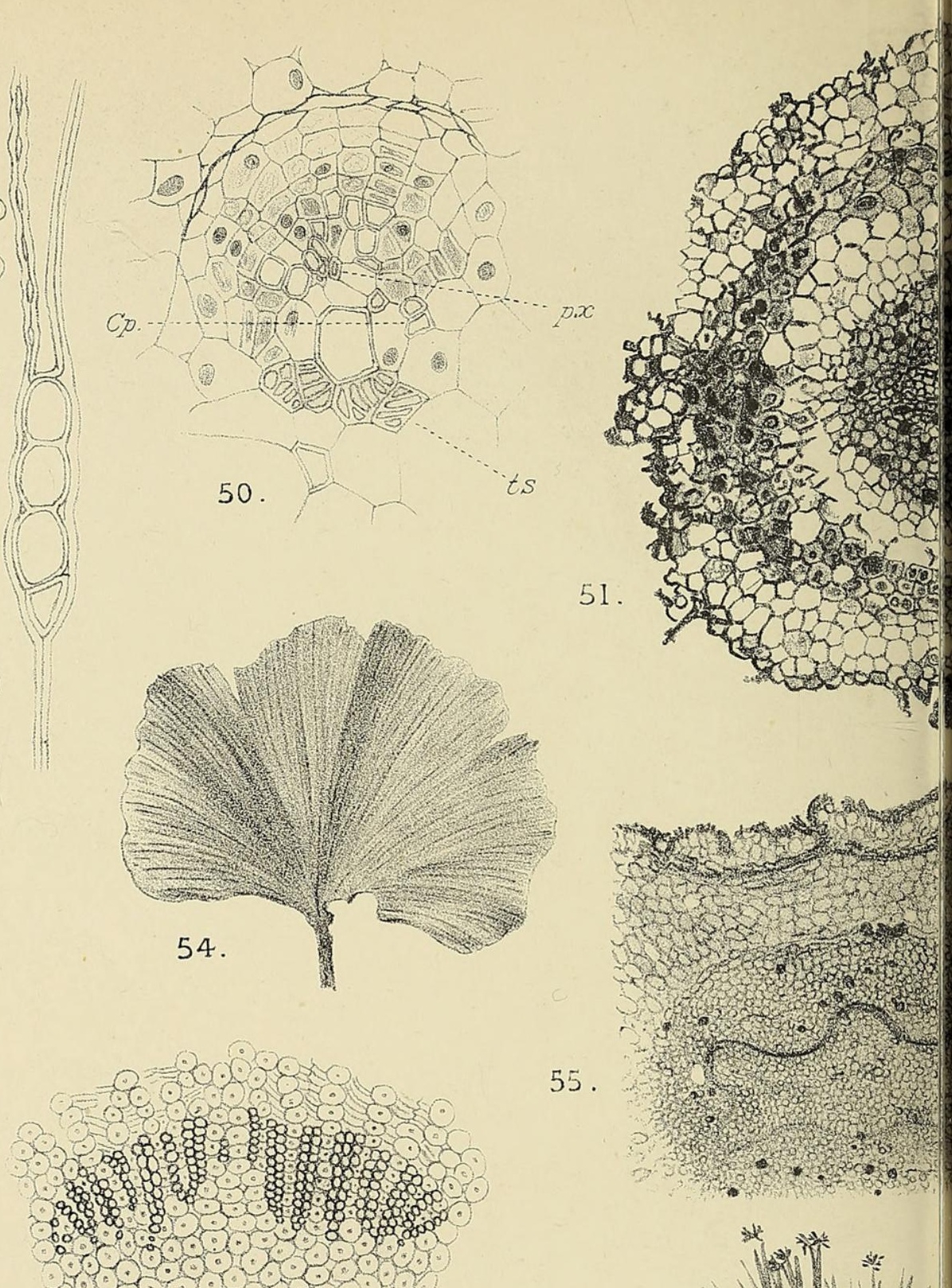

59.
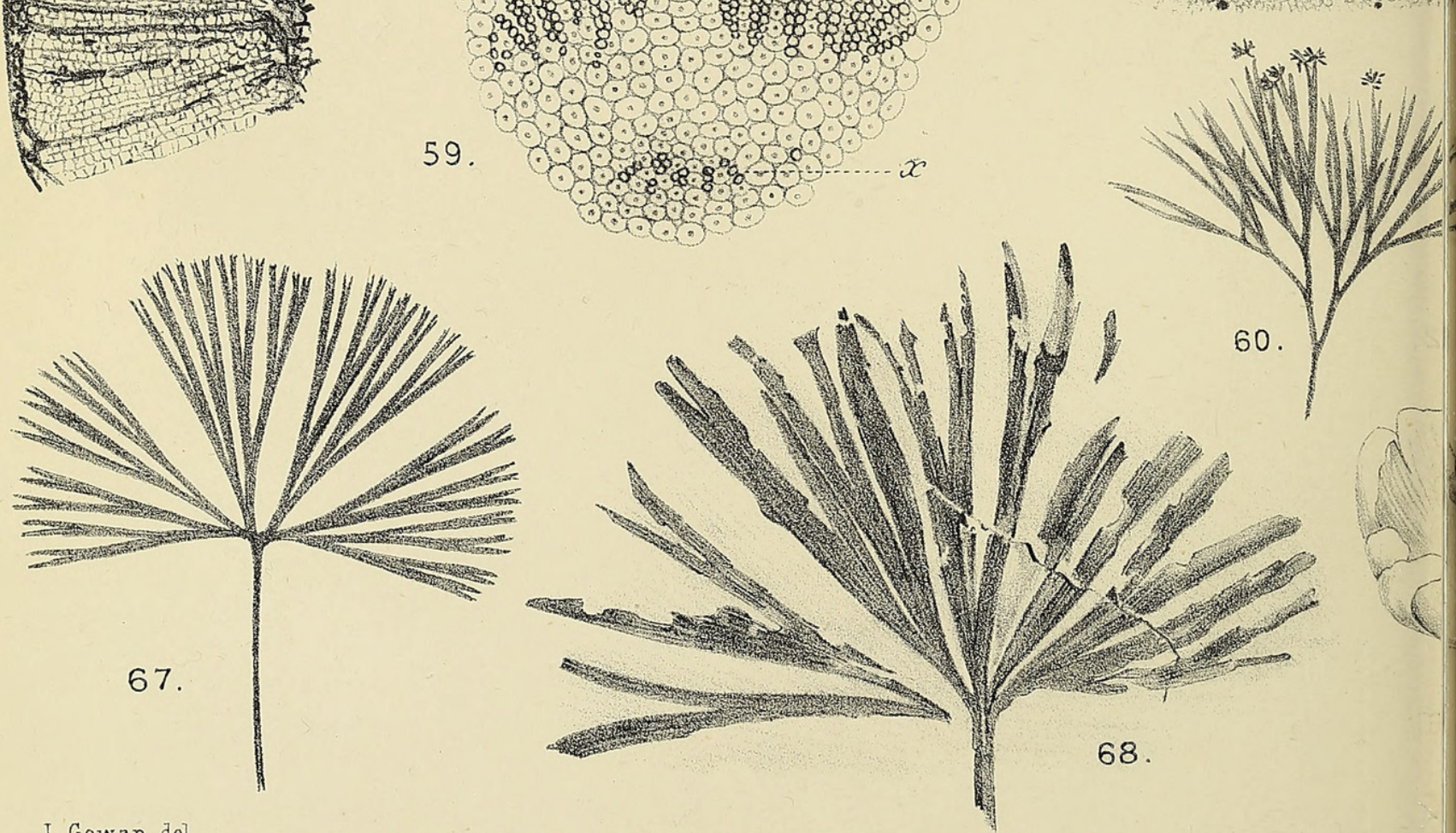

J. Gowan del.
$S E W A R D$
$-O N$
$G \quad N \quad K \quad G \quad O$. 

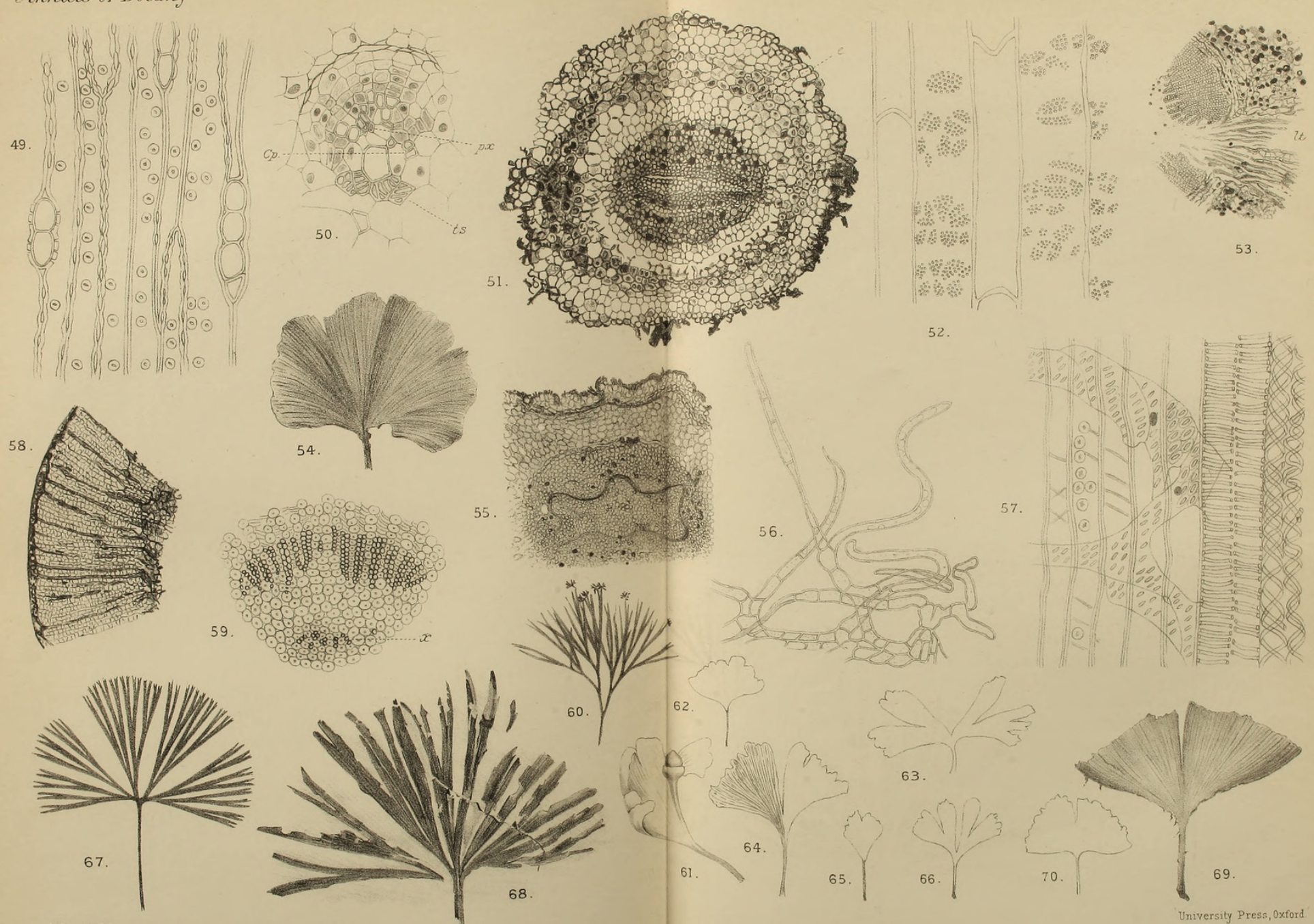

J. Gowan del.
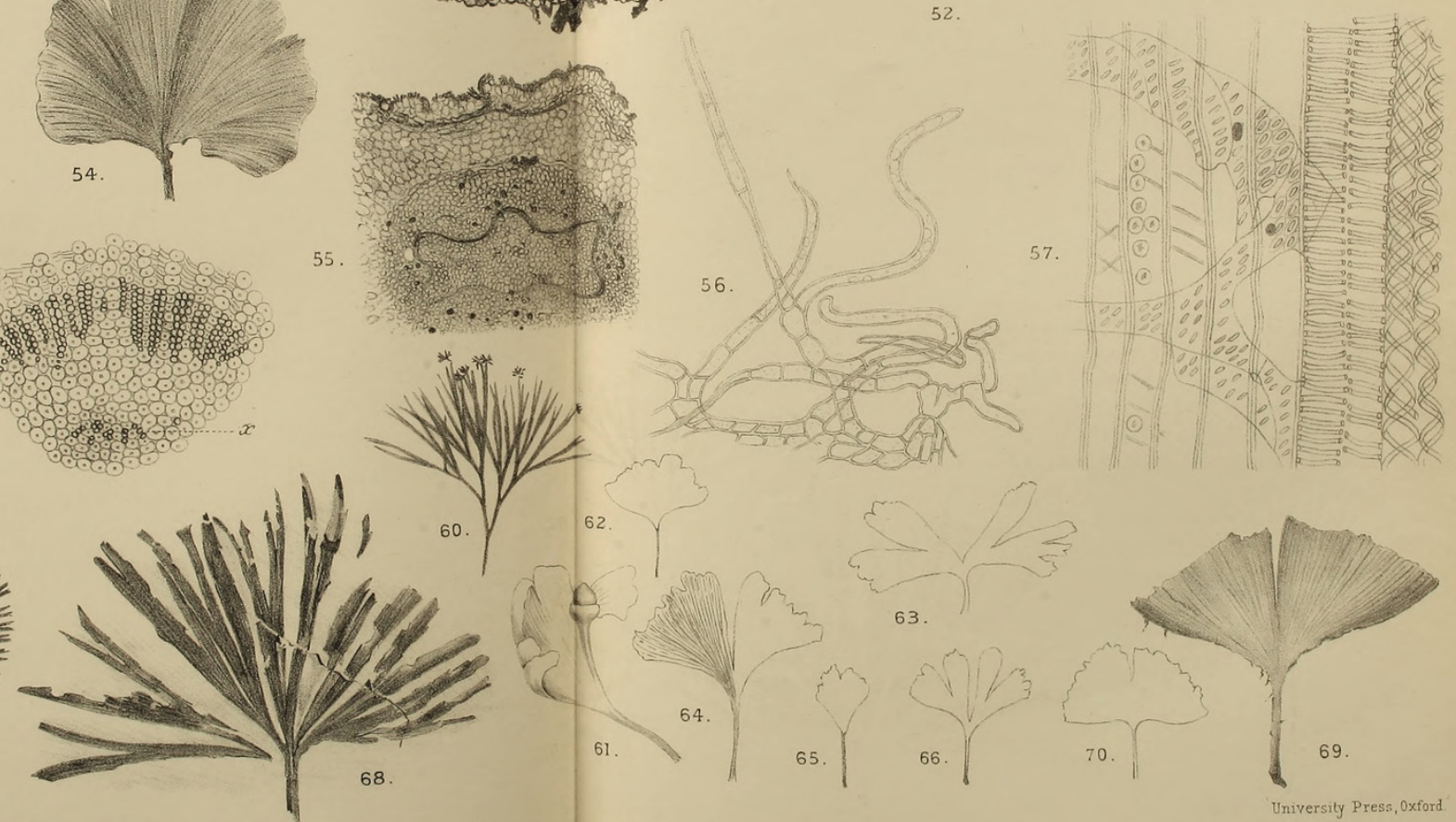

$S E W A R D-O N G I N K G O$
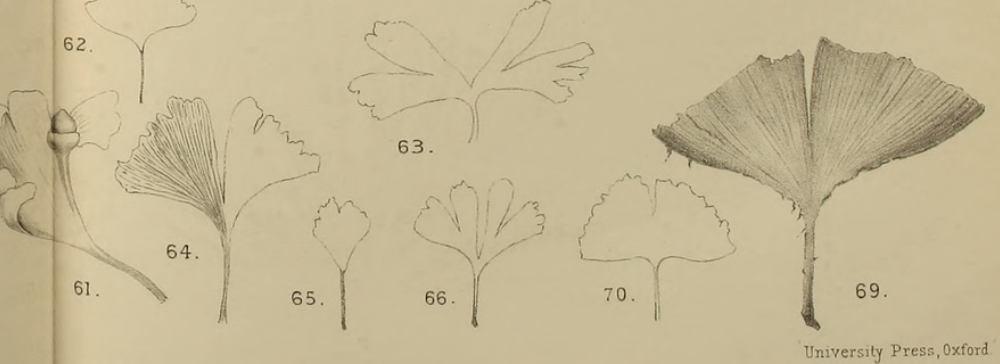

University Press, 0xford 


\section{$2 \mathrm{BHL}$ Biodiversity Heritage Library}

Seward, A C and Gowan, J. 1900. "The maidenhair tree (Ginkgo biloba, L.)." Annals of botany 14, 109-154.

https://doi.org/10.1093/oxfordjournals.aob.a088765.

View This Item Online: https://www.biodiversitylibrary.org/item/238259

DOI: https://doi.org/10.1093/oxfordjournals.aob.a088765

Permalink: https://www.biodiversitylibrary.org/partpdf/318575

\section{Holding Institution}

Smithsonian Libraries

\section{Sponsored by}

Biodiversity Heritage Library

\section{Copyright \& Reuse}

Copyright Status: Not in copyright. The BHL knows of no copyright restrictions on this item.

This document was created from content at the Biodiversity Heritage Library, the world's largest open access digital library for biodiversity literature and archives. Visit BHL at https://www.biodiversitylibrary.org. 